\title{
RECENT ADVANCES IN BIOTECHNOLOGY IN ANIMAL HEALTH
}

\author{
Umar Farooq Gohar, Zinnia Shah, Javaria Sarwar, Hiba Akram and Hamid Mukhtar
}

Institute of Industrial Biotechnology (IIB), Government College University, Lahore 540oo, Pakistan

*Corresponding author: dr.mufgohar@gcu.edu.pk

\section{INTRODUCTION}

The past 30-35 years have witnessed rapid development in the field of biotechnology; the applications which were once only anticipated ideas of technological expertise have finally come to fruition. With the increase in population, changing diet patterns, changing purchase priorities and urbanization-conventional methods of improving food productivity can no longer serve the augmenting consumer demands. It is of no surprise that human health and welfare is directly linked to animal health and welfare, thus where conventional methods are failing to keep up with the rapidly changing trends, modern biotechnological techniques, in contrast, provide pioneering opportunities for enhancing livestock yield, productivity, health, and welfare. These include the deployment of various modern biotechnological tools (Figure 1), which have effectively contributed towards meliorating product enrichment; ensuring food safety; development of powerful diagnostic and therapeutic tools; catering efficient utilization of scarce resources and shrinking the livestock environmental footprint. High end objectives, such as to promote resource sustainability, increase profitability and alleviate food insecurity, are now being widely pursued side by side, however, implications in respect of legal, bioethical and ethno-religious nature continue to pose challenges to the progression of these intense advancements. This paper reviews the multiplicity of biotechnological applications in animal nutrition and health and attempts to evaluate the potential risks involved in projected undertaking of these modern practices.

Utilization of feed additives and other exogenous substances for livestock improvement

As the human population is roughly estimated to surge from 7.6 billion (2017) to 9.8 billion by the year 2050 (Nations 2017), various reports have predicted the need of either doubling up (Tilman et al. 2011; Alexandratos and Bruinsma 2012) or at least grow livestock productivity (termed as "Livestock Revolution") by $25-60 \%$ in the coming years (Hunter et al. 2017) to satisfy the predicted increase in demand for milk and meat (Thornton 2010; Alexandratos and Bruinsma 2012). Three major constraining factors are widely known to influence the productivity of livestock sector; these are (i) low quality feed resources, (ii) high feed cost (Sujani and Seresinhe 2015; Aslam et al. 2020), and (iii) presence of antinutritional factors (Ramteke et al. 2019), as shown in
Figure 1, these result in weight loss, compromised immunity, and natural abortions etc. The quality of meat or its by-products is massively influenced by the type and quality of feed stuff fed to livestock (ruminants and nonruminants alike). Animal nutritionists have, therefore, developed and practiced various chemical, physical and biological methods of feed improvement over the past few decades. With the growing awareness regarding food safety, biological methods have gained the most prominence and acceptance at large which include efforts to formulate highly nutritional and profitable growth promoters and promising feed additives (Sujani and Seresinhe 2015). The utilization of a variety of nutrient/non-nutrient feed additives, or exogenous health improving drugs, have therefore proved to be effective options for improving the plane of nutrition, enhancing nutrient utilization by animals and reducing food waste. Common examples include immunostimulants, pre-/pro-biotics, essential oils, feeding attractants, antibiotics and other inclusions such as binders, acidifiers, vitamins, enzymes and hormones, which can either be administered as feed additives or subcutaneous dosage. The use of feed additives is a commonly adopted practice for enhancing swine and poultry production and is now gaining recognition for ruminant diets as well. Biotechnological advances have a fair share in adding convenience to the production and availability of these compounds, the following is an account of some major commercially available bio-engineered products manufactured through applications of modern biotechnology.

\section{Enzymes}

Enzymes have been used directly or indirectly throughout human history in food manufacturing (Campbell and Bedford 1992; Classen 1993; Perry 1995; Bedford 1996; Bhat 2000; Buchholz and Bornscheuer 2017). The commercially produced exogenous enzymes, such as phytase, gulcanase, and cellulase, are added to feedstuff to improve its nutritive value which is otherwise hampered due to the presence of anti-nutritive and indigestible factors. 'Phytase' is the most commonly used enzyme-additive which when added to monogastric feed, increases the digestibility of phytate (an inositol hexakisphosphate) from around $25 \%$ to $50-70 \%$ (Ravindran et al. 1999 ; Ravindran et al. 2000; Kornegay 2001) and, therefor, increases the bioavailability of phosphorus for nonruminant livestock (Fuller 1989). Phytase is also known to improve the digestibility of amino acids (Zhang and Kornegay 1999) and other nutrients, and improves feed 
energy value as well (Ravindran et al. 1999; Ravindran et al. 2000; Kornegay 2001).

Xylanase (also pentosanase), a family of enzymes known to break xylan (component of hemicellulose) into digestible xylose, is another such example used as a feed additive in monogastric diets. Likewise, glucanases and cellulases are widely used to improve the ileal digestibility of non-starch polysaccharides (NSPs) (Hesselman and Åman 1986; Broz and Frigg 1986; Newman and Newman 1987; Campbell et al. 1989; McDonald et al. 2010). The use of fibrolytic enzymes in feeds to improve digestibility of fiber is also a well-adopted practice in livestock farming, especially in monogastric diets. Although, the rumen microbiome has the natural ability to digest the plant lignocellulosic biomass and convert it into high quality milk and meat for human consumption, studies have proved that the use of exogenous fibrolytic enzymes in ruminant diets also renders beneficial effects of increasing the digestibility of neutral detergent fibre in dry matter diets and crop residues to support higher productivity (Oba and Allen 1999; Jung et al. 2004; Tirado-Gonzalez et al. 2018; Refat et al. 2018; Beauchemin et al. 2019). In short, by increasing the digestibility of components like lignin, cellulose, hemicellulose, non-starch polysaccharides and fiber, these enzymes help maximize feed productivity (Prasad and Roy 2018), nutrient digestibility (Salem et al. 2011) and consequentially promote animal growth and production (Sujani and Seresinhe 2015).

Industrial production of bioengineered enzymes is now steadily growing; most of these are extracted from GRASstatus (Generally Recognized as Safe) microorganisms, including bacterial, fungal and yeast sources; a few, however, are extracted from plant or animal tissues as well. Usually, either the production organism or the product enzymes are genetically modified to achieve the desired enzyme yield and functional efficacy. The microbial population is the most exploited source for enzyme production, as it provides easy and high yield harvesting (Filer 2003); B. subtilis, B. amyloliquefaciens, $B$. licheniformis and B.stearothermaphillus are the most extensively reported industrial enzyme producers (Aslam et al. 2020). Moreover, the vast amount of microbial genomic information at hand and the increased understanding of microbial gene expression systems, favor the forging for suitable microorganisms from newer microhabitats. Enzyme production method from microorganisms is simple and a general step-wise procedure is outlined in Figure 3. Submerged liquid fermenters are the traditional choice for harvesting microbially derived enzymes. Moreover, solid-substrate fermenters are also used as an alternative (Singhania et al. 2010).

\section{Hormones}

Russel Marker, a chemistry professor at The Pennsylvania State College, invented a degradation process to produce affordable steroidal hormones in 1938. This process was named "Marker Degradation" which is also known as "His path-breaking process" and became the founding stone of the steroid industry in Mexico. The process to produce progesterone from diosgenin is shown in Figure 4. It was precisely this process which helped Marker to produce his first kilo of progesterone and within a year the Mexican steroid company, Syntex, was selling progesterone for $\$ 50$ per gram.

In the following years, due to issues related to profit shares, Marker shifted his work to another company in Mexico, the Gedeon Ritcher Limited, and started producing progesterone under the name Hormonosynth, which was later reorganized as Diosynth (Bohning and Morris 1999). This marked the introduction of synthetic

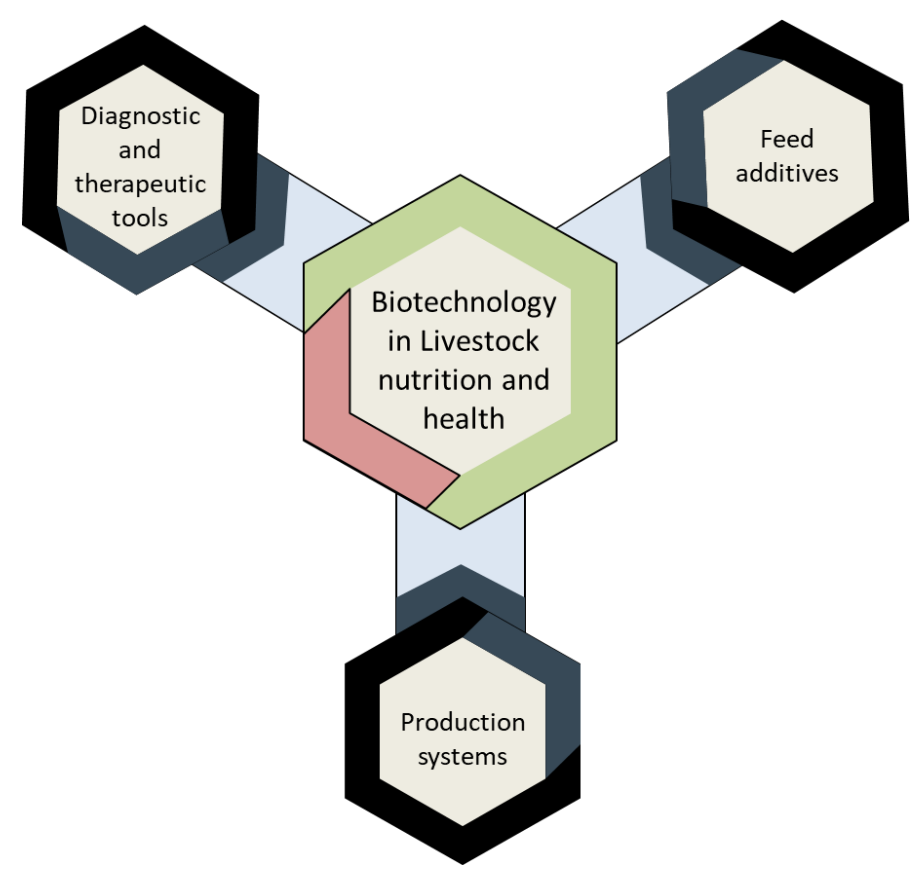

Figure 1: Major biotechnological domains in livestock improvement.

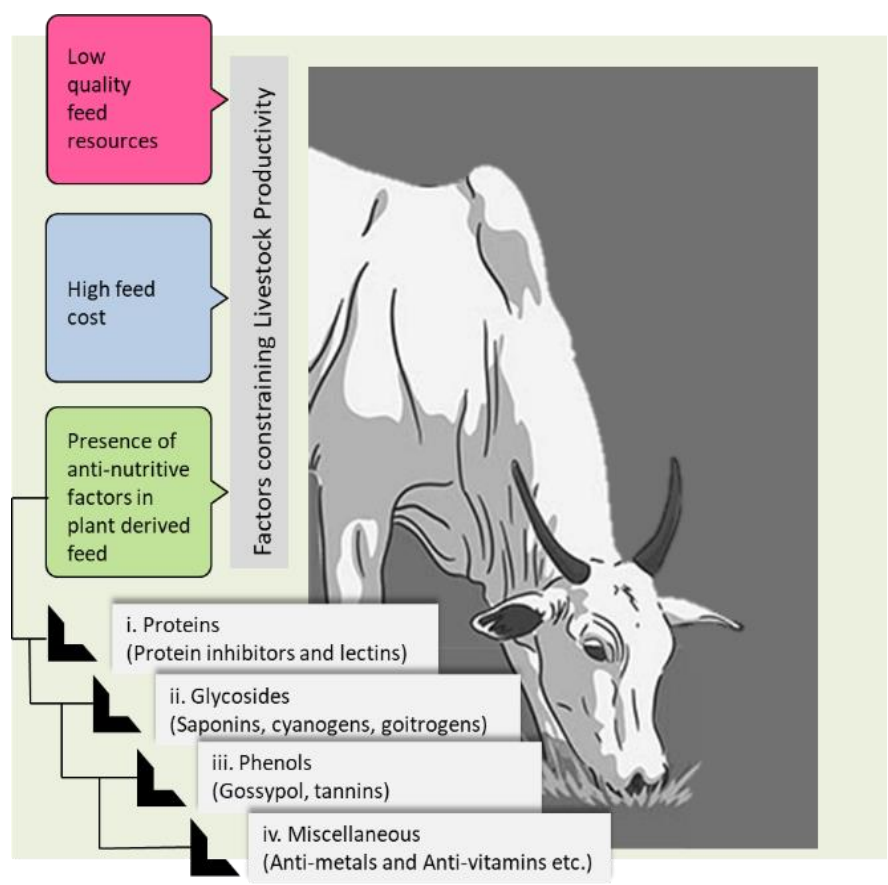

Figure 2: The major constraining factors known to negatively influence livestock productivity. 


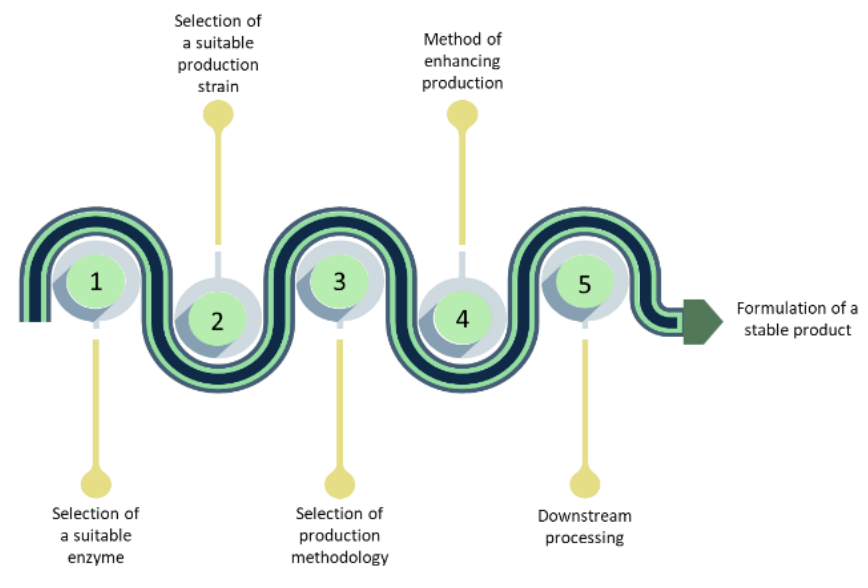

Figure 3: Steps involved in microbially derived commercial enzyme production.

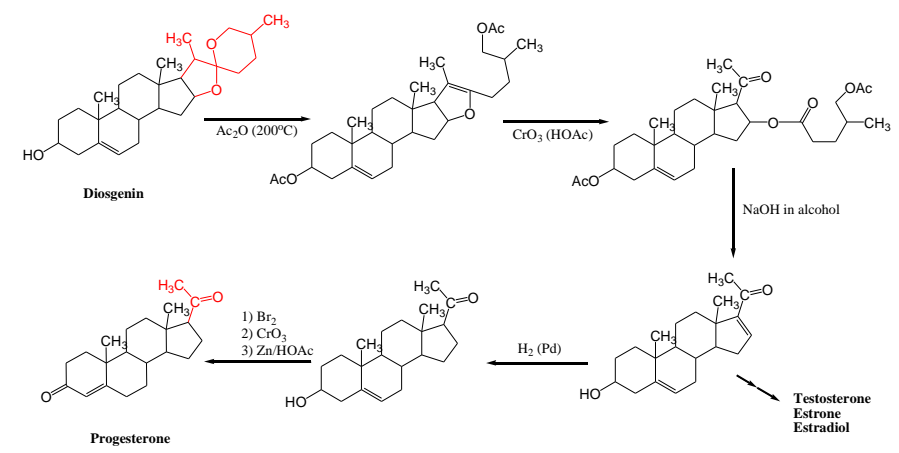

Figure 4: The series of steps involved in production of progesterone from diosgenin, through the process called 'Marker Degeneration'.

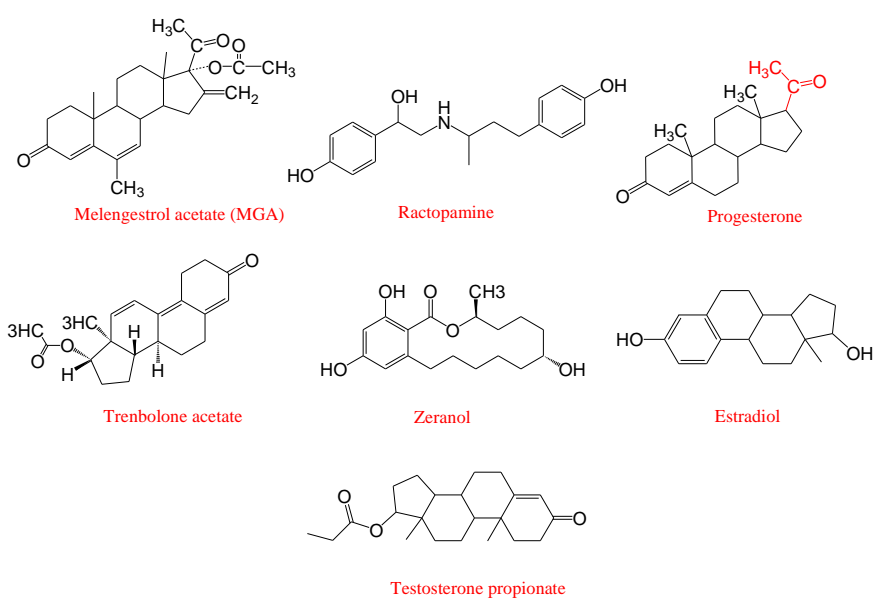

Figure 5: Chemical structures of Melengestrol acetate (MGA), ractopamine, progesterone, trenbolone acetate, zeranol, estradiol and testosterone propionate - the only hormones approved by the FDA for use in food animals. MGA and ractopamine are approved as livestock feed additives, whereas the rest of them are used in the form of 'pellets' which are installed subcutaneously, most probably as 'ear implants' where the pellets are installed at the back of the ear and is discarded before the animal is utilized for its meat or byproducts to avoid health complications. The risk, however, remains even after the pellet region is removed and so use of hormone pellets - no doubt its positive potential - is a rarely adopted method in livestock farming. hormones in the market; however, the public acceptance grew slowly and the application of exogenous hormones to promote growth is still taken to be the least encouraged practice of all.

Only two hormones, melengestrol acetate (MGA) (Meissonnier and Mitchell-Vigneron 1983) and ractopamine (Marchant Forde et al. 2003), have yet been authorized by the US Environmental Protection Agency and the FDA for use as feed additives. MGA (synthetic progesterone, structure shown in Figure 4) belongs to the most active synthetic gestagens and is used for estrus synchronization or inhibition in cattle or beef animals (Duncan et al. 1964), therefore improving their weight gain and feed efficiency. Ractopamine, on the other hand, is a phenol-based agonist of TAAR1 and $\beta$ adrenoreceptors; and is known to promote leanness in meat, along with increasing food digestibility in farm animals (Colbert et al. 1991; Liu et al. 2014). Various other natural and synthetic hormones are also administered to livestock but these are in the form of implants, especially ear-implants, and are directed towards enhancing growth by interfering with the hormonal cycles of recipient animals. Unlike other feed additives, the use of hormones is rather restricted due to the solemn health-associated risk factors. Ractopamine, for instance is approved only in certain regions of America and banned in almost all others. Various other natural/synthetic-hormone-based products, however, are administered otherwise in the form of pellets to increase animal growth rate and reduce lipid deposition. Overall, these hormones are androgenic, corticosteroidal, estrogenic, progestagenic, $\beta$-adrenergic and thyreostatic compounds, which can be administered separately or in combinations as required (Stephany 2009). The FDA has approved a total of six hormone drugs, namely; bovine somatotropin (peptide hormone), estradiol, progesterone, trenbolone acetate (anabolic steroidal ester), testosterone propionate (anabolic androgen steroid), and zeranol (non-steroidal estrogen agonist) for use in animals to enhance growth and productivity (FDA 2021), as shown in Figure 5. None of the hormones are approved for use in swine or poultry, however in ruminants the results include weight gain, improved feed efficiency and increased milk production in dairy animals. Table 1 highlights the indications, availability status and livestock species approved for hormone administration.

After Marker's success story, in year 1951, a microbial process of converting oxidized progesterone to cortisone was introduced by scientists at another Mexican company, the Upjohn Co., using Syntex's progesterone (Bohning and Morris 1999). Since then, the industrial production of steroidal hormones and drugs, which are otherwise difficult to obtain through conventional methods, has become the best known application of microbial biotransformation (Fernandez et al. 2003; Fernandez and Cabral 2010; Vom Steeg and Klein 2017; Cano-Flores et al. 2020). Figure 6 shows how bacteria are utilized to produce recombinant bovine somatotropin (rBST) (Shakweer 2008); rBST is administered to increase milk production in dairy cows and improve feed efficiency as well. Likewise, 
Table 1: The attributes of different hormones used in livestock industry

\begin{tabular}{|c|c|c|c|c|c|c|c|}
\hline \multirow[t]{2}{*}{ Attributes } & \multicolumn{7}{|c|}{ Hormone } \\
\hline & BST & $\mathrm{E}_{2}$ & $\mathrm{~T}$ & $\mathrm{P}$ & TBA & $\mathrm{Z}$ & MGA \\
\hline Approved for - & Dairy & $\begin{array}{l}\text { Steer, Bull, Heifer, } \\
\text { Calf }\end{array}$ & Heifer & $\begin{array}{l}\text { Steer, Bull, } \\
\text { Calf }\end{array}$ & $\begin{array}{l}\text { Calf, Bull, Steer, } \\
\text { Heifer, Cow }\end{array}$ & $\begin{array}{l}\text { Steer, Bull, Calf, Sheep, } \\
\text { Lamb, Cattle }\end{array}$ & Beef \\
\hline $\begin{array}{ll}- & \text { Weight gain } \\
- & \text { Feed efficiency } \\
- & \text { Estrus } \\
- & \text { Milk production }\end{array}$ & & & & & & & \\
\hline Availability - & OTC & OTC & OTC & OTC & OTC & OTC & OTC \\
\hline
\end{tabular}

${ }^{*} B S T$ : Bovine somatotropin, E2: Estradiol, T: Testosterone, P: Progesterone, TBA: Trenbolone acetate, Z: Zeranol, MGA: Melengestrol acetate, OTC: Over the counter.

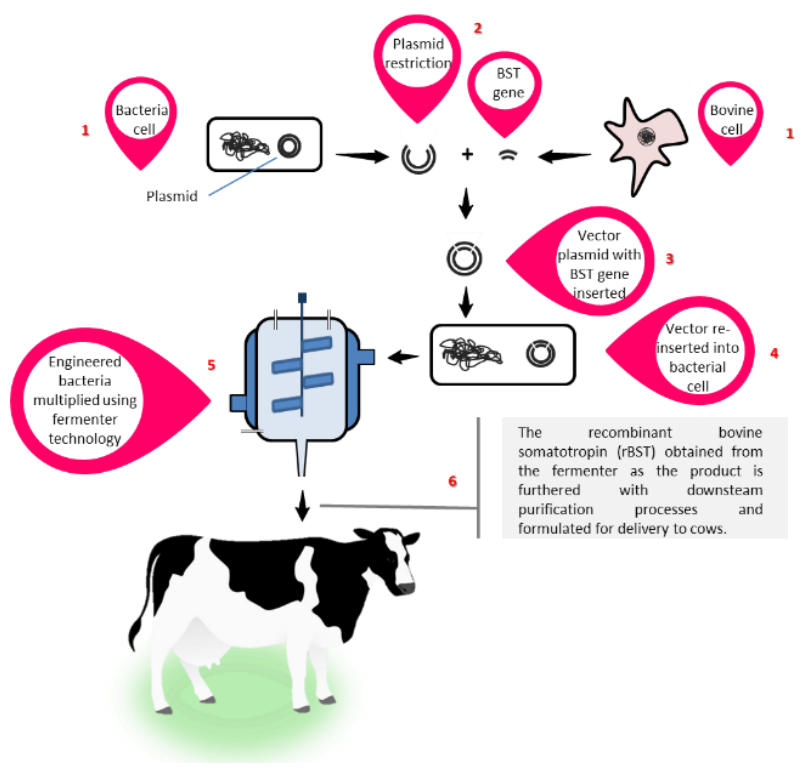

Figure 6: Production procedure of recombinantly derived bovine somatotropin (rBST). The method produces sufficient rBST for commercialization and safe enough to be administered in place of BST extracted from pituitary glands of slaughtered animals.

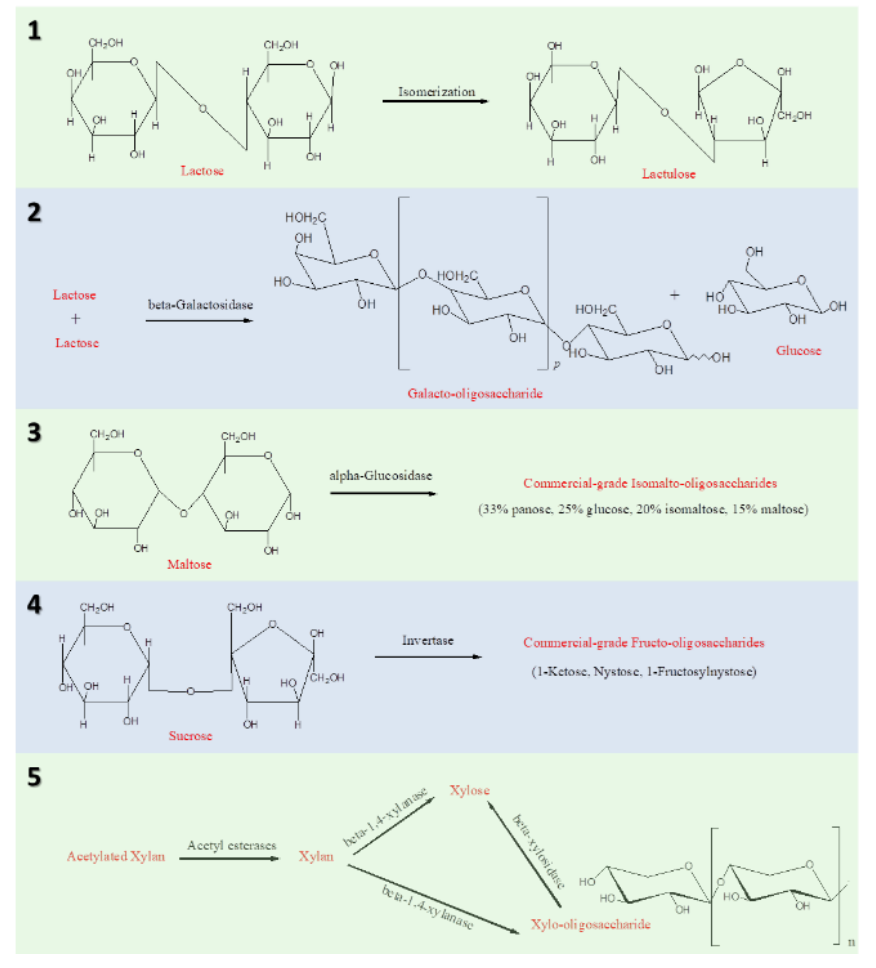

Figure 7: The structures and commercial enzymatic-production of prebiotic ingredients for livestock feed. recombinantly derived porcine somatotropin (PST) is a variant used to improve leanness, reduce carcass fat content and enhance growth rate in swine particularly. The use of recombinantly derived BST and PST has also been reported to reduce environmental footprint of livestock industry (Etherton et al. 1993).

\section{Prebiotics, probiotics and synbiotics}

Prebiotics and probiotics are not drugs; prebiotics are nutritive ingredients (WHO 1994), while probiotics are live microbial supplements which can restore intestinal microbial balance (FEFANA 2005). These do not act directly on the host but functions indirectly by modulating the gut microbiota, either through causing changes to the proportions of its resident microorganisms or by influencing activity of intestinal health-promoting microorganisms (Gibson and Roberfroid 1995). Gut microbiota is known to influence various functions related to the animal health, including fermentation and digestion of nondigestible substrates, trophic effects on the immunity, adding protection against invasion by nonnative microbes, better absorption of ions in the intestines, and lastly the production of vitamins (B9, B12, K) and amino acids (Guarner 2007). Thus, the use of prebiotics and probiotics in animal feed indirectly supports improvement of animal health, production and welfare on a significant scale.

Prebiotics are selectively fermented, non-digestible ingredients. These dietary ingredients are intended to be consumed by bifidobacterial and lactobacilli species, which are known to reside in large intestine and have been reported to exert prophylactic and therapeutic influences on animal health.

Commonly used prebiotics for livestock include synthetic saccharides such as lactulose, isomalto-oligosaccharides, transglacto-oligosaccharides, fructo-oligosaccharides (Grajek and Sip 2004) and cereal fibre (Crittenden and Playne 2009; Olveira and Gonzalez-Molero 2016); their structures shown in Figure 7. In order for any ingredient to be classified as a prebiotic, there is a certain criterion for it to befit (Wang 2009; Śliżewska et al. 2013), as shown in Figure 8, and even if the ingredient fulfills all the criteria, its efficacy, effectiveness and efficiency depends on a number of factors, such as the condition of animal's present gut microbiota, the dosage and its frequency, and especially its 'prebiotic index' i.e. "the increase in the absolute number of bifidobacteria expressed divided by the 
Table 2: Different prebiotics for livestock feed, their production enzymes, enzyme source and enzyme substrates

\begin{tabular}{|c|c|c|c|c|c|c|}
\hline \multirow[t]{2}{*}{ Prebiotic } & \multirow[t]{2}{*}{$\mathrm{BC}$} & \multirow[t]{2}{*}{ Source of BC } & \multirow[t]{2}{*}{ Substrate(s) } & \multicolumn{2}{|l|}{ OWC } & \multirow{2}{*}{ References } \\
\hline & & & & $\overline{\mathrm{pH}}$ & Temp $\left({ }^{\circ} \mathrm{C}\right)$ & \\
\hline \multirow{11}{*}{$\begin{array}{l}\text { Galacto- } \\
\text { oligosaccharide }\end{array}$} & \multirow[t]{10}{*}{$\beta$-galactosidase } & Bifidobacterium longum & \multirow[t]{11}{*}{ Lactose } & 6.8 & 45 & Hsu et al. 2007 \\
\hline & & Enterobacter agglomerans & & $7 \cdot 5$ & 50 & Lu et al. 2007 \\
\hline & & Geobacillus-stearothermophilus & & 6.5 & 37 & Placier et al. 2009 \\
\hline & & RiogW & & 7.0 & 40 & Chockchaisawasdee et \\
\hline & & Kluyveromyces lactis & & 6.5 & 30 & al. 2005 \\
\hline & & L. reuteri & & 6.5 & 30 & Splechtna et al. 2006 \\
\hline & & L. acidophilus & & $5 \cdot 4$ & 50 & Nguyen et al. 2007 \\
\hline & & Penicillium expansum $\mathrm{F}_{3}$ & & 6.0 & 80 & Li et al. 2008 \\
\hline & & Sulfolobus solfataricus & & 6.5 & 40 & Park et al. 2008 \\
\hline & & $\begin{array}{l}\text { Talaromyces thermophillus } \\
\text { Thermatoga maritime }\end{array}$ & & 6.0 & 80 & $\begin{array}{l}\text { Nakkharat et al. } 2006 \\
\text { Ji et al. } 2005\end{array}$ \\
\hline & B- glycosidase & Rhodotorula minuta IFO879 & & 5.0 & 60 & $\begin{array}{l}\text { Onishi and Tanaka, } \\
1996\end{array}$ \\
\hline \multirow{9}{*}{$\begin{array}{l}\text { Fructo- } \\
\text { oligosaccharides }\end{array}$} & B- & A. Pullulans & \multirow[t]{5}{*}{ Sucrose } & 5.0 & 50 & Yoshikawa et al. 2007 \\
\hline & fructofuranosidase & Aspergillus japonicas & & 5.0 & 50 & Mussatto et al. 2009 \\
\hline & Fructosyltransferase & Aspergillus aculeatus & & 5.6 & 60 & Nemukula et al. 2009 \\
\hline & G- & Erwinia Rhipontici NCPPB 1578 & & $6.0-6.5$ & 30 & Mundra et al. 2007 \\
\hline & \multirow{2}{*}{ fructofuranosidase } & Xanthophyllomyces dendrorhous & & 7.0 & - & Chen et al. 2011 \\
\hline & & Erwinia sp. D12 & $\begin{array}{l}\text { Sugarcane } \\
\text { molasses }\end{array}$ & 6.4 & 45 & Kawaguti et al. 2011 \\
\hline & \multirow[t]{3}{*}{ Inulinase } & \multirow{3}{*}{$\begin{array}{l}\text { Kluyveromyces marxianus var. } \\
\text { bulgaricus } \\
\text { Xanthomonas Campestris }\end{array}$} & \multirow[t]{2}{*}{ Sucrose } & 5.0 & 50 & Santos and Maugeri, \\
\hline & & & & 7.0 & 37 & 2007 \\
\hline & & & Inuline, tryptone & & & Naidoo et al. 2009 \\
\hline \multirow[t]{2}{*}{$\begin{array}{l}\text { Isomalto- } \\
\text { oligosaccharides }\end{array}$} & Trans-glucosidase & $\begin{array}{l}\text { Saccharomyces carlsbergensis } \\
\text { Saccharomyces cerevisiae }\end{array}$ & $\begin{array}{l}\text { Starch from rice } \\
\text { crumbs }\end{array}$ & - & - & Pan and Lee, 2005 \\
\hline & $\begin{array}{l}\text { Dextranase and } \\
\text { dextransucrase }\end{array}$ & - & Sucrose & 6.0 & 50 & Zhang et al. 2010 \\
\hline \multirow{6}{*}{$\begin{array}{l}\text { Xylo- } \\
\text { oligosaccharides }\end{array}$} & \multirow{6}{*}{$\begin{array}{l}\text { B-xylosidases } \\
\text { Xylanase }\end{array}$} & Aspergillus nidulans FGSC $\mathrm{A}_{4}$ & Xylose & 5.2 & 40 & Dilokpimol et al. 2011 \\
\hline & & Paecilomyces themophila & Xylan & 7.0 & 70 & Teng et al. 2010 \\
\hline & & Pichia pastoris & Cellulose & 6.0 & 65 & Jun et al. 2009 \\
\hline & & Pichia stipites & Xylan & $5 \cdot 4$ & 50 & Yang et al. 2011 \\
\hline & & Thermobifidia fusca & Xylan & $7 \cdot 5$ & 60 & Huang et al. 2010 \\
\hline & & Thermoascus aurantiacus & Sugarcane bagasse & 5.0 & 50 & Brienzo et al. 2010 \\
\hline
\end{tabular}

*BC: Bio-Catalyst, OWC: Optimum Working Condition.

daily dose of prebiotic ingested" (Roberfroid 2007). There are various enzymatic and chemical treatment methods to industrially produce prebiotic ingredients from lignocellulosic material; these methods include extraction of substrate saccharides by steam, alkaline solutions and diluted solutions of mineral acids.

Once the substrate saccharide is successfully extracted, various commercially available enzymes (Table 2) are used to catalytically produce the required prebiotic (Garrote and Parajo 2002; Palm and Zacchi 2003; Vazquez et al. 2005; Aachary and Prapulla 2011; Basu et al. 2015; Sorndech et al. 2018). Galacto-oligosaccharides are produced through transglycosylation of lactose (Chen et al. 2003; Panesar et al. 2006), fructo-oligosaccharides are produced through transfructosylation of sucrose or through hydrolysis of inulin (Oscara et al. 2007; Chen et al. 2011); likewise, through hydrolysis xylan, xylo-oligosaccharides are produced (Kubik et al. 2004; Doukyu et al. 2007; Sato et al. 2010) and the debranching and hydrolysis of oligosaccharides result in the production of jsomaltooligosaccharides (Lee et al. 2002; Zhang et al. 2010).

The use of probiotics to achieve better livestock health and productivity dates back to the 1970's. Intentional addition of specific live microorganisms to livestock feed has shown to promote eubiosis and preclude disruption of intestinal equilibrium (FEFANA 2005). Different types of probiotics exert their effects in different modes of action, these include; (i) Competitive elimination of potentially harmful pathogens through competing for adhesion sites in the gut wall and competing for nutrients or organic substrates (Umesaki et al. 1997; Hughes and Heritage 2002; McDonald et al. 2010; Cho et al. 2011); (ii) Bacterial antagonism - once the probiotic microorganisms establish in the gut, they may produce bactericidal or bacteriostatic substances to ward off unwanted bacterial species from the gut (Hughes and Heritage 2002; Steiner 2009; McDonald et al. 2010); (iii) Neutralization of enterotoxins; probiotic microorganisms produce a range of substances which include antioxidants, organic acids and bacteriocins (McDonald et al. 2010). The presence of these substances in the gut establish anti-microbial environment (Alakomi et al. 2003), which specifically targets the metabolism and toxin production mechanisms of pathogenic bacteria; and lastly, (iv) Immune modulation; probiotics have been studied to support animal's defense against harmful invaders by stimulating the production of antibodies and increased phagocytic activity (Hughes and Heritage 2002; McDonald et al. 2010; Ahasan et al. 2015). Anything about improvement in carcass characteristics or milk yield in dairy cows upon receiving probiotics remains debatable 


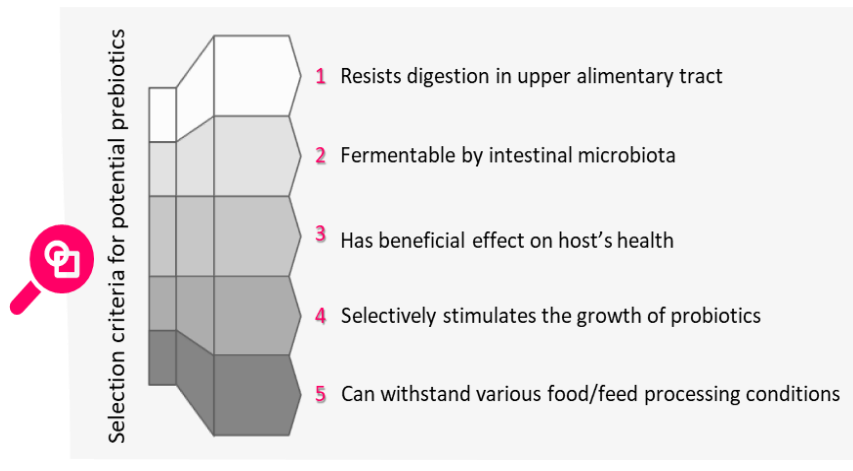

Figure 8: Selection requirements for potential prebiotics.

Table 3: The various microorganisms (by genus and specie) which are regarded as safe and healthy consumable probiotics

\begin{tabular}{|c|c|}
\hline Genus & Probiotic species \\
\hline \multirow[t]{2}{*}{ Aspergillus } & A. Oriza \\
\hline & A. Niger \\
\hline \multirow[t]{3}{*}{ Bacillus } & B. cereus \\
\hline & B. licheniformi \\
\hline & B. subtilis \\
\hline \multirow[t]{5}{*}{ Bifidobacterium } & B. bifidum \\
\hline & B. lactis \\
\hline & B. longum \\
\hline & B. pseudolongum \\
\hline & B. thermophilum \\
\hline \multirow[t]{2}{*}{ Enterococcus } & E. faecalis \\
\hline & E. faecium \\
\hline \multirow{9}{*}{ Lactobacillus } & L. acidophilus \\
\hline & L. amylovorus \\
\hline & L. rhamnosus \\
\hline & L. fermentum \\
\hline & L. brevis \\
\hline & L. farmicinis \\
\hline & L. casei \\
\hline & L. reuteri \\
\hline & L. plantarum \\
\hline Lactococcus & L. lactis \\
\hline \multirow{3}{*}{ Leuconosto } & L. lactis \\
\hline & L. citreum \\
\hline & L. mesenteroides \\
\hline \multirow[t]{2}{*}{ Pediococcus } & P. pentosaceus subsp. Pentosaceous \\
\hline & P. acidilactici \\
\hline \multirow{2}{*}{ Saccharomyces } & S. pastorianus \\
\hline & S. cerevisiae \\
\hline \multirow[t]{2}{*}{ Streptococcus } & S. salivarius \\
\hline & S. infantarius \\
\hline
\end{tabular}

and holds a huge area for research and further study (Yirga 2015). Indications regarding growth and feed efficiency however, are positively reported in heifers and steers, especially with increase in the concentration of feed propionibacterium and L. acidophilus (Galyean et al. 2000; McPeake et al. 2002). Table 3 enlists the various probiotic microorganisms (Yirga 2015) and Table 4 provides the common benefits of using probiotics in monogastric and ruminant diets.

The substantial evidence of probiotic usefulness is found to be matched with an equal number of denigrators as well (Swinney-Floyd et al. 1999; Rust et al. 2000). However, the use of prebiotics is widely accepted as an effective practice for the above-noted cause. The major consideration while forming an impression on the degree of a pre/pro-biotic's usefulness is the fact that it is a variable factor, as it depends on the nature of the additive (type of prebiotic/strain of probiotic), its stability in the host system, the dosage, frequency of administration, offtarget interactions and host-factors i.e. age, nutritional status, health and genetics etc. As human population is expected to grow, the market size for pre- and pro- biotics is also anticipated to increase at $\sim 12 \%$ CAGR for prebiotics by the year 2026 (Mordor 2021) and at $\sim 7 \%$ CAGR for probiotics by the year 2027 (Transparency 2019). The synergistic combination of pre- and pro-biotics has also evoked high hopes, such a combination is called a 'synbiotics'. As the term itself implies, the prebiotic component serves to selectively favor the activity of probiotic component (Cencic and Chingwaru 2010); the purpose behind this combination is thus apparent to improve the survival tendency of probiotic microorganisms in the gut (Rioux et al. 2005). Considering the superior activity of synbiotics in comparison to individual potential of both pre- and pro-biotics, the application of synbiotics to improve livestock health and productivity seems better promising than its individual component (Scavuzzi et al. 2014), as it helps lower concentration of undesirable metabolites (Bengmark and Martindale 2005) and can guarantee profitability; however, the various possibilities still require further studies.

\section{Antibiotic growth promoters (AGPs) and alternatives}

The growth promoting effects of antibacterial compounds were discovered in 1940, as a result of adding by-products of tetracycline fermentation to poultry diet (Phillips et al. 2004). The application of antimicrobial compounds to livestock feed has since increased (Aust et al. 2008; Zuccato et al. 2010; Gao et al. 2012) by as much as 10-20 folds (Brown et al. 2017). Such an intense rise is the consequence of an ever-growing consumer demand for food-animal products, and so AGPs - also interchangeably - 'veterinary antibiotics' (VAs) (Phillips et al. 2004) now represent a large proportion of the global antibiotic consumption. In 1940's and 1950's, AGP administration became an essential component of the animal protein factor' (APF) feed supplement, as it deemed necessary for balancing poultry and swine rations. Moreover, pharmaceutical compounds do not bioaccumulate in significant amounts within the body, excessively high proportions of VAs got excreted via milk (Halling-Sorensen et al. 2001; Arikan et al. 2009), eggs (Idowu et al.2010), urine and feces (Ostermann et al. 2013) in non-metabolized form; however, later studies proved the accumulation of VAs in edible tissues as well (Kwon et al. 2011; Kim and Schrenk 2012). Thus, these antibiotic residues get transferred into human diet and pose serious threats to consumer health, either through causing unwanted reactions such as allergies (Phillips et al. 2004), or increasing the risk of transferring antibiotic resistance (Butaye et al. 2003). Figure 9 shows the timeline of AGP acceptance and banning in various parts of the time of their discovery. 
Table 4: Some probiotics of potential use in livestock industry with their benefits

\begin{tabular}{lll}
\hline Livestock animal & Probiotic microorganism & Common benefits \\
\hline Veal Calf & B. pseudolongum & Promotes weight gain \\
& L. acidophilus & Limits rumen acidosis \\
L. animalis & Improves feed digestibility \\
S. paracasei & Improves milk yield \\
Swine & B. subtilis & Limits shedding of human pathogens \\
B. cereus & Reduces risk of intestinal diseases \\
B. licheniformis & Decreases stress \\
E. faecium & Increases litter size and vitality \\
E. faecalis & Reduces risk of intestinal diseases (diarrhea, constipation) \\
L. acidophilus & Improves feed digestibility \\
L. reuteri & Improves milk and meat quality \\
L. johnsonii & \\
S. cerevisiae & \\
\hline
\end{tabular}

Table 5: Biological implications of livestock feed acidifiers

Digestive system Immune system

- Increase villus height

- $\quad$ Lower Gut $\mathrm{pH}$

- Lowers pathogenic bacteria

- Increase gastric retention time

- Modifies intestinal microflora

- Improve nutrient digestibility

- Improve mineral absorption

- Improves feed utilization
Immune system

- Increases immunoglobulins

- Enhances antibody production

- Increases serum albumin

- Stimulates immune system

- Enhances immune response
Performance and health indices

- Improves liver health

- Improves lipid profile

- Antioxidant activity

- Mitigates ammonia emission

- Mitigates urea excretion

- Alleviates heat stress

- Improves meat and carcass quality

- Antimicrobial activity

- Improves reproductive performance

Table 6: The beneficial role and deficiency symptoms for micronutrients in ruminant diets

Micronutrient Benefit Deficiency symptom

Boron (B) Enzyme function

Cobalt (Co) Energy assimilation and vitamin B12 function

Copper $(\mathrm{Cu}) \quad$ Hemoglobin formation, enzyme function and pigments

Iodine (I) Thyroid gland function

Iron (Fe) Protein, hemoglobin and enzyme function

Manganese (Mn) Enzyme function

Selenium (Se) Vitamin E function

Zinc (Zn) Enzyme function

Understanding the precise mode of action of AGPs has been a challenging task due to the complexity of the intestinal environment and numerous possible interactions therein. In 1963, a study carried out on growth enhancing effects of APGs on germ-free mice led to the observation that growth enhancement was a factor of the presence of microorganisms (Coates et al. 1963); promulgating the idea that gut-microbiota modulation is the primary operating mechanism of APGs (Dibner and Richards 2005). Currently, two primary hypotheses have been worked out i.e. an AGP either acts in a bacteriacentric manner or a host-centric manner. Either way, a further multitude of factors including effects of AMR within the gut, diverse microenvironments, the physiology of the host animal, the environment wherein livestock has been maintained, nutritional status and stress complicate the study due to their strong associations with each other. Figure 10 illustrates the working mechanistic of both hypotheses. Due to the serious risks associated
Low conception rates, depressed immunity, brittle bones

Anemia, depressed immunity, infertility, poor growth, exudate from eyes, loss of coat

Anemia, poor growth, digestive problems, bone disorders, brain and spinal cord lesions, infertility, discoloration of hair

Goitre and reproductive failure

Anemia

Skeletal abnormalities, stunted growth, reproductive failure, ataxia in newborns

White muscle disease, poor growth, infertility

Stiff and swollen joints

(Chattopadhyay 2014), WHO has strictly prohibited the use of antimicrobials as growth promoters and limited its use to prescription only (WHO 2003; WHO 2004), as the production benefits fail to compensate for the higher costs of AGPs (Graham et al. 2007) and associated health concerns. Today, various potentially active and safer alternative compounds are being explored, examples include antimicrobial peptides (Yoon et al. 2013), pre-/probiotics, natural extracts, phytochemicals and polyphenols (Guo et al. 2004a; Guo et al. 2004b; Ohno et al. 2013; Salim et al. 2013; Khadem et al. 2014; Lei et al. 2015; Rostami et al. 2015).

\section{Acidifiers}

Acidifiers are organic acids, which have been known for their preservative, prophylactic and nutritional qualities in livestock feed industry since long (Spratt 1985; Partanen and Morz 1999). These specificities are attributed to the 


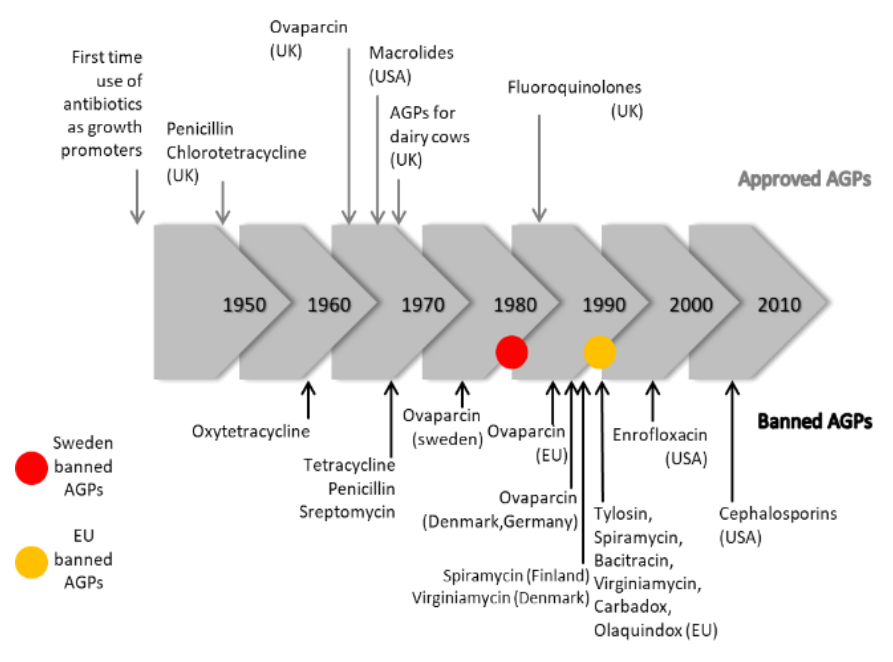

Figure 9: Timeline of antibiotic growth promoters (AGPs).

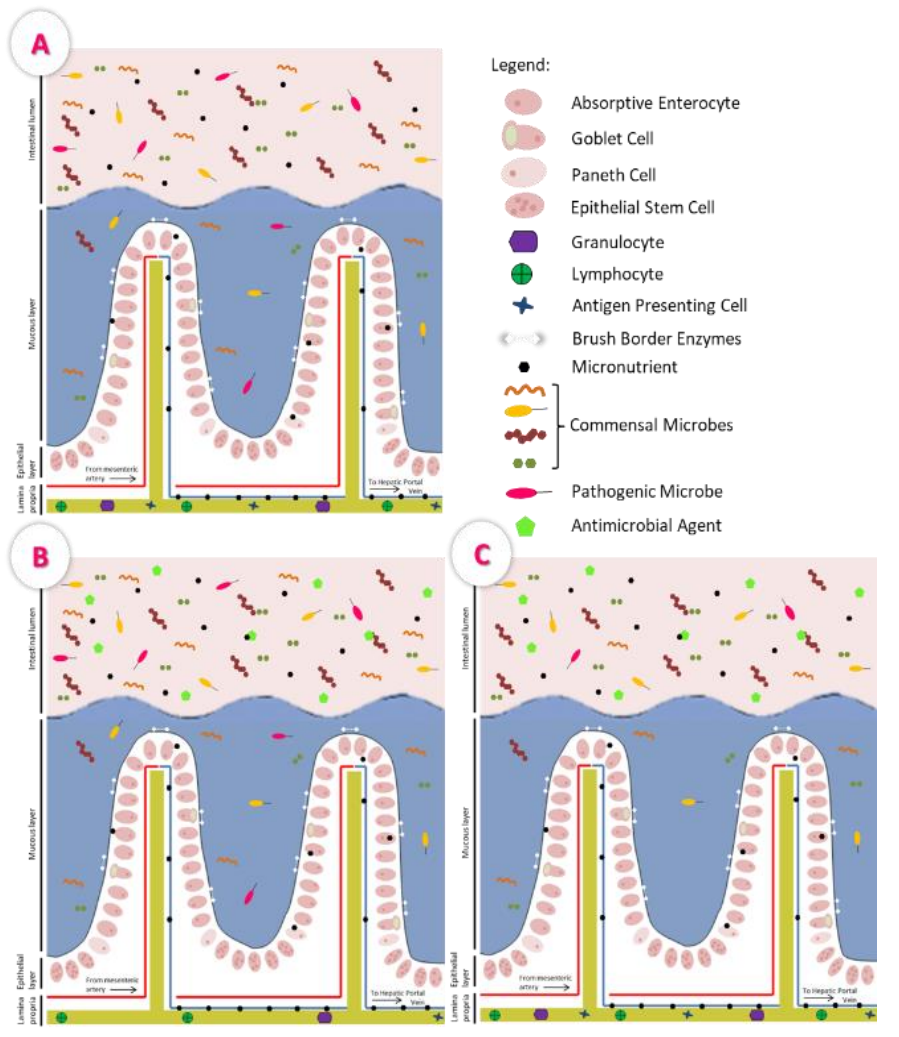

Figure 10: Intestinal immune-metabolism nexus: (A) The normal intestinal homeostasis; (B) bacteria-centric hypothesis - AGPs may alter the composition of microbiota to reduce competition for nutrients; (C) host-centric hypothesis - AGPs act as immunomodulatory agents by shifting resources to metabolic function.

carboxyl functional group $(-\mathrm{COOH})$ of these acids. Various studies have confirmed acidifiers as a costeffective option for enhancing growth, performance, and productivity in animals (Roth et al. 2017), as they help in diminution of pathogens in the gut, improved nutrient digestibility, enhanced eubiosis in intestinal microbiota (Overland et al. 2009; Ndelekwute et al. 2019) and as a consequence improve the overall livestock production economy.

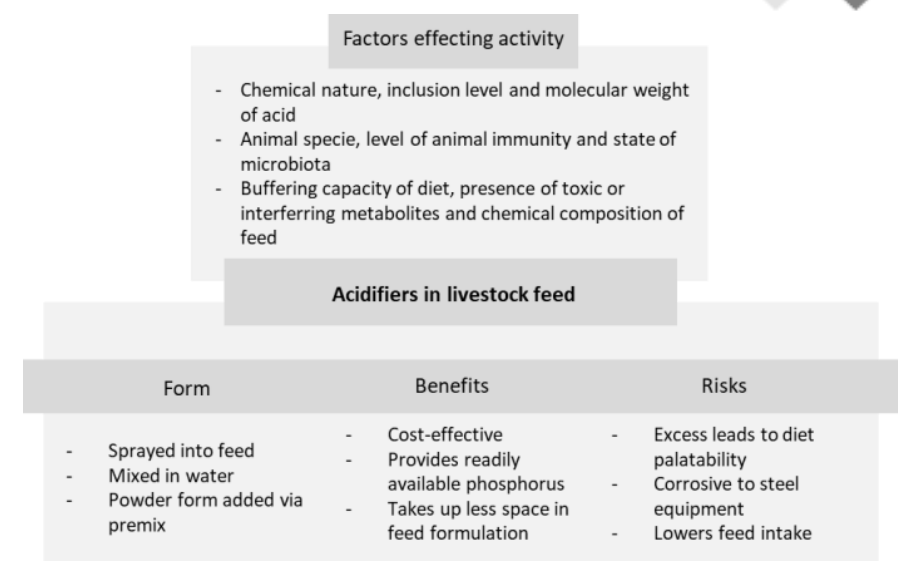

Figure 11: Characteristics, benefits, risks and factors influencing the use of acidifiers in animal feed.

Figure 11 summarizes the characteristics, benefits, risks, and factors influencing the use of acidifiers in animal feed. Table 5 enlists the biological activities of acidifiers when added to livestock feed (pearlin et al. 2019). With the discussed advantages, a few concerns regarding their action mechanism, palatability and neutralization still remain, which demand further study regarding their impact on consumer health and livestock economical footprint.

\section{Other feed additives and growth promoters}

Synthetic additives and growth promoters have farreaching effects in enhancing growth and productivity of animals. The downside to their use, however, can neither be ignored nor avoided. Therefore, alternatives have been sought of organic forms as a means of equally effective biofortification in livestock production. Agronomic influence on livestock feed remains to be the foremost problematic concern, when it comes to compromised nutritional quality of economic produce. Various possible solutions to this include formulation of microelementenrich feed and use of plant-derived antimicrobial peptides.

Deficiency of micronutrients causes grave restraints on animal health and growth, hence soil enrichment through balanced fertilization has long been practiced widely (Fisher 2008). Today, advancements have brought functional innovations, including the domain of nanoparticles which allows efficient infusion of highly dispersed and scarce micronutrients in feed mixtures. Due to their structure and developed surface, nanomaterials elicit intensified biological activities. Therefore, infusion of nutrients with the help of nanotechnology ensures their uniform distribution in the feed, the later serves as stable and much efficient source of scarce trace elements for animals (Belov et al. 2020). Micronutrients are essential for animal health, and it must be noted that their deficiency leads to the development of various clinical or subclinical implications, such as reduced fertility, browning of hair and compromised immunity (Fisher 2008). The main roles and deficiency symptoms for micronutrients in ruminant livestock are shown in Table 6. 
Antimicrobial peptides (AMPs) are a family of around 5000 short cationic-peptides which elicit antibacterial or host-defense activities (Ganz 2002; Waghu et al. 2014; Ageitos et al. 2017). Utilization of these peptides is a safe alternative to the use of antibiotics in livestock feed. Studies have shown that dietary supplementation with AMPs for animals can improve rumen digestion, performance, growth, intestinal morphology, nutrient retention, and host immunity (Wu et al. 2012; Yoon et al. 2012; Yoon et al. 2013; Choi et al. 2013; Lee et al. 2014). As AMPs consist of amino acids only, they are easily modifiable and can be produced on an industrial scale through recombinant expression systems (Bahar and Ren 2013). Table 7 enlists the different AMPs applicable to swine feed and their application effects. With several beneficial properties including lowering risk of antimicrobial resistance, enhancing host immunity, excellent disease inhibitory effects and ease of degradation, AMPs represent one of the most promising alternatives to antibiotics. However, their inconsistence efficacy, instability, susceptibility to proteolysis and high cost of production has prevented AMPs from reaching an economically effective market size ( $\mathrm{Li}$ et al. 2018).

\section{Animal Health and Welfare}

After ensuring the provision of best nutritional formulations for animals, the next immediate step is the assurance of disease diagnostic, preventive, and treatment strategies. The broad magnitude of biotechnological advancements today has made it possible to precisely detect and specifically eliminate the developing infection or disease in question. Hence, this section is divided into three parts: Diagnosis, prevention and treatment approaches to animal diseases and infections.

\section{Diagnosis of animal diseases}

Detection of previous exposures to potentially harmful pathogens and prompt diagnosis of prevalent diseases has always been a vital part of animal health assurance and maintenance (McKeever and Rege 1999). For several years, this had been executed through application of various macroscopic and microscopic techniques involving different culturing methods and body fluid examinations of the infected animal. Although reliable, these methods had a number of shortcomings and limitations that impeded the progress in the field of animal health. Incorporation of biotechnological techniques in the animal diagnostic studies proved to be immensely beneficial for the scientific community, as it improved the specificity and sensitivity of different diagnostic methodologies along with shortening the required testing time, enabling immediate control of various animal diseases before they could affect a vast population. This fusion also allowed the researchers to extend their approach towards detection and control of various congenital or genetically transmitted diseases that affected animal productivity and health of the whole animal lineage (Myers-Keith 1983; Yanchinski 1983; Jindal and Sharma 2010). Biotechnological techniques employed to detect and identify various disease-causing factors can be generally grouped under five categories: (i) Conventional methods, (ii) DNA-based diagnostic techniques, (iii) Antigen-antibody interaction-based techniques, (iv) Pen-side tests, and (v) Metabolite-based techniques Figure 12). A brief account of these techniques is given below.

\section{Conventional methods}

The traditional culturing techniques for isolation and detection of causative agents are still the gold standard methods for detection of disease-causing microorganisms. These include; media cultures to obtain bacterial isolates and cell cultures to assess viral infections. Despite being the gold-standard methods, these methods are more time consuming, labor-intensive, have higher risk of contamination and are less sensitive compared to the advanced diagnostic tools, as they rely on phenotypicbiochemical characterization (Saminathan et al. 2016).

\section{DNA-based diagnostic techniques}

Nucleic acid amplification/polymerase chain reaction

Nucleic acid amplification technique, or polymerase chain reaction technique, is a type of DNA-based assay that involves the amplification and synthesis of a distinct nucleic acid sequence present exclusively in the pathogen to be detected. This enzymatic amplification assay of the DNA target molecule comprises a repeated cycle of target molecule denaturation, hybridization to specific primers through DNA polymerases and elongation of the primers, leading to the production of a large number of copies of the particular nucleic acid sequence. This assay has proved to be rather sensitive and specific, enabling rapid diagnosis of an infectious disease (Rodriguez 1997); a titer minimum of 0.01 TCID (tissue culture infective dose) of viral RNA can be identified in the infected tissue culture fluid by a single-step, highly sensitive derivative technique: RT-PCR-ELISA, which proves to be 10,000 times more sensitive than RT-PCR (Rajeev et al. 2011; Sharma et al. 2015). Furthermore, incorporation of fluorescent probes and dyes e.g. Taqman hydrolysis probe or SYBR Green dye, for the simultaneous analysis of the amplified pathogenic sequence through Real-Time PCRs have revolutionized infectious disease diagnosis and control in the veterinary medicine. This technique is also being used in combination with a number of other diagnostic assays, allowing a more far-stretched approach of the diagnosticians towards the detection of pathogenic agents of veterinary significance (Zarlenga and Higgins 2001; Borroto 2009; Balamurugan et al. 2014). Some of the various disease causing agents that are being detected through this technique in animals are Foot and mouth disease virus (FMDV), Porcine parvovirus (PPV), Bovine herpes virus, Pseudo rabies virus, Morbillivirus, Yersinia Entercollitica, Mycobacterium species and Enterotoxigenic Escherichia coli (ETEC) (Rodriguez 1997). 
Animal disease diagnostic tools

\begin{tabular}{|c|c|c|c|c|}
\hline $\begin{array}{l}\text { Conventional } \\
\text { tests/assays }\end{array}$ & $\begin{array}{l}\text { DNA-based } \\
\text { techniques }\end{array}$ & $\begin{array}{l}\text { Antigen-antlbody } \\
\text { based techniques }\end{array}$ & Pen-side tests & $\begin{array}{l}\text { Metabolite- } \\
\text { based assays }\end{array}$ \\
\hline $\begin{array}{l}\text { - RBPT } \\
\text { - STAT } \\
\text { - } \text { ELISA } \\
\text { - MRT } \\
\text { - Media/cell cultures } \\
\text { - } \text { Biochemical tests for } \\
\text { bacteria } \\
\text { - Neutralization assays } \\
\text { for virus } \\
\text { Merits: } \\
\text { - Gold-standard for } \\
\text { most pathogens } \\
\text { Demerits: } \\
\text { - Labor intensive } \\
\text { - Time consuming } \\
\text { - Less sensitive }\end{array}$ & $\begin{array}{l}\text { - } \text { PCR } \\
\text { - } \text { RT-PCR } \\
\text { - } \text { q-PCR } \\
\text { - RFLP } \\
\text { - FISH } \\
\text { Merits: } \\
\text { - Rapid } \\
\text { - High sensitivity and } \\
\text { specificity } \\
\text { - Can aid in detection } \\
\text { of multiple } \\
\text { pathogens } \\
\text { Demerits: } \\
\text { - Risk of biohazard } \\
\text { - Costly instruments } \\
\text { - Requires skilled } \\
\text { - } \text { workers } \\
\text { - Short-half life }\end{array}$ & $\begin{array}{l}\text { - ELISA } \\
\text { - Dipstick assay } \\
\text { - LFA } \\
\text { - Biosensors } \\
\text { Merits: } \\
\text { - Sensitive and } \\
\text { Specific } \\
\text { - Uses common } \\
\text { transfusers: } \\
\text { Electrochernistry, } \\
\text { reflectochemistry, } \\
\text { flourometry } \\
\text { (Biosensors) } \\
\text { Demerits: } \\
\text { - Biosafety issues } \\
\text { - Needs high skilled } \\
\text { persons } \\
\text { - High cost for } \\
\text { sampling } \\
\text { (Biosensors) }\end{array}$ & $\begin{array}{l}\text { - LAMP } \\
\text { - LFA } \\
\text { Merits: } \\
\text { - Easy to perform } \\
\text { - Rapid } \\
\text { - Sensitive and specific } \\
\text { - Does not require } \\
\text { post-amplification } \\
\text { protocols }\end{array}$ & $\begin{array}{l}\text { - Proteomics } \\
\text { - Nanoparticles } \\
\text { - Nanobarcodes } \\
\text { - Quantum dots } \\
\text { - Comparative } \\
\text { isoenzyme analysis } \\
\text { Merits: } \\
\text { Very sensitive } \\
\text { Very accurate } \\
\text { Can be used for early } \\
\text { detection of diseases } \\
\text { Demerits: } \\
\text { Requires highly skilled } \\
\text { person }\end{array}$ \\
\hline
\end{tabular}

Figure 12: The various biotechnological tools for animal disease diagnosis, their approaches, merits and demerits.

Table 7: AMPs authorized for use in swine feed and their application effects

\begin{tabular}{|c|c|c|}
\hline AMP & Application Effects & Reference \\
\hline $\mathrm{AMP}-\mathrm{A}_{3}$ & $\begin{array}{l}\text { Improves performance, nutrient digestibility, intestinal morphology, gut } \\
\text { microbiota }\end{array}$ & Yoon et al. 2012 \\
\hline $\mathrm{AMP}-\mathrm{P}_{5}$ & Reduced coliforms, improves performance and nutrient digestibility & Yoon et al. 2013 \\
\hline AMP cecropin AD & $\begin{array}{l}\text { Improves performance, immune status, energy retention, reduces } \\
\text { intestinal pathogens }\end{array}$ & Wu et al. 2012 \\
\hline AMP colicin E1 & Reduce probability of diarrhea, improves performance & Cutler et al. 2007 \\
\hline $\begin{array}{l}\text { CAMP (Lectoferrin-Defensin- } \\
\text { Active yeast) }\end{array}$ & $\begin{array}{l}\text { Improves feed efficiency, intestinal morphology, protein synthesis, } \\
\text { intestinal epithelial cell proliferation, antioxidant capacity, lipid and } \\
\text { energy metabolism, alleviates organ damage. }\end{array}$ & $\begin{array}{l}\text { Xiao et al. 2013a; Xiao } \\
\text { et al. 2013b; Xiao et al. } \\
2015\end{array}$ \\
\hline $\begin{array}{l}\text { cipB-lactoferricin- } \\
\text { lactoferrampin }\end{array}$ & $\begin{array}{l}\text { Improves absorption of iron, improves performance, reduces incidence } \\
\text { of diarrhea, improves performance }\end{array}$ & Tang et al. 2008 \\
\hline $\begin{array}{l}\text { Recombinant Lactoferrampin- } \\
\text { Lactoferricin) }\end{array}$ & Affects serum parameters, improves performance & Tang et al. 2012 \\
\hline $\begin{array}{l}\text { Mixture: lactoferrin, defensing, } \\
\text { cecropin and plectasin }\end{array}$ & $\begin{array}{l}\text { Reduce probability of diarrhea, Improves performance, increases } \\
\text { survival rate }\end{array}$ & Xiong et al. 2014 \\
\hline
\end{tabular}

\section{Restriction fragment length polymorphism (RFLP)}

RFLP is among the earliest molecular techniques used for DNA profiling and gene mapping. This is a DNA-based diagnostic technique that employs the fact that even the homologous genetic makeup of closely related species comprises of variation sequences or polymorphism in their genetic arrangement. This assay begins with the reverse transcription of the pathogenic DNA, followed by digestion of the nucleic acids with the help of specific restriction enzymes. The resultant fragments are then separated and detected through gel electrophoresis and various blotting and dying techniques, respectively. Ideally, the generated pattern is unique to each pathogenic strain, revealing its distinct fingerprint or genetic makeup. Although beneficial in the diagnosis of various veterinary diseases, its use is greatly decreased in the recent years due to introduction of more sensitive and efficient techniques(Jindal and Sharma 2010; Dai and Long 2015).

\section{Nucleic acid hybridization technique}

This technique primarily involves synthesis of nucleic acid probes complementary to the genetic sequence present specifically in the genomic or plasmid DNA of the pathogen to be detected. Once paired, the probe-nucleic acid complex is detected through various radioactive or non-radioactive reporter molecules. Employed mainly for the detection of fastidious organisms such as Mycoplasma and Mycobacterium, this technique ensures early diagnoses by surpassing the long culturing time required by such pathogenic species. Some of the various veterinary infections causing entities that are identified through this technique include Adenovirus, Bovine viral diarrhea virus, bursal disease virus, Campylobacter species, Leptospira species, Anaplasma marginale and Histoplasma capsulatum. Besides being simply a diagnostic technique, this probe-based assay has also been used for genetic mapping of homology among closely related organisms, determination of pathogenic mechanisms on a molecular 
level and differentiation of virulent from avirulent strains. Acquisition of such detailed information about the genomics of the pathogens has unfolded a rather meticulous approach towards disease diagnostic studies for the veterinary researchers and diagnosticians (Paul 1990; Sinigaglia et al. 2018).

\section{Antigen-antibody interaction-based techniques}

\section{Monoclonal antibodies}

The conventional diagnostic measures used for the identification of disease-causing agents were immensely dependent on rather time consuming and hectic culturing techniques. With the introduction of monoclonal antibodies in the field of disease diagnostics, the efficiency of the already existent detection strategies was greatly enhanced. This assay utilizes the basic mechanism of the immune system that involves production of antigen specific immunoglobulins in response to the infectious pathogen or its various constituents. Hence, the presence of such antibodies in the serum of the animal proves the occurrence of the corresponding disease. The antibody titer measurement can further provide insight into the severity of the infection. Use of monoclonal antibodies was initially based of differential diagnosis of the vaccine strains from field strains of the pathogen due to their high specificity. This technique is now used for the identification of various veterinary infectious diseases such as Feline leukemia, Trypanosomiasis and Colibacillosis (Kahi and Rewe 2008; Jindal and Sharma 2010).

\section{Enzyme-Linked Immunosorbent Assay (ELISA)}

ELISA surpasses the previously present precipitationbased antigen-antibody assays by incorporating an enzyme with one of the reactants, most commonly the antibody, for the purpose of detection and quantification. It is an extremely sensitive technique capable of detecting very minute quantities of the target material. It is carried out on a solid phase, to which different components are presented in a sequential manner. The reacting and nonreacting components are separated from each other through washing after each step, making it a heterogenous assay. Due to its high specificity, versatility, precision and reproducibility, this antigen antibody based technique is preferred over other sero-diagnostic methods for the detection and diagnosis of various veterinary infectious diseases (Clark et al.1986). Some of the many such animal diseases against which ELISA kits have been manufactured for are Brucellosis, Rabies, Canine Distemper and Canine Parvo virus, Canine Hepatitis virus, Foot and Mouth disease, New Castle Disease and Egg Drop Syndrome virus-76 (Jindal and Sharma 2010).

\section{Immunoblotting assay}

Western Blotting is a technique that provides a mean for identification of various target epitopes related to the infection causing pathogen through application of antibodies from the infected animals, or separately synthesized monoclonal antibodies against the specific antigen. This assay combines the specificity of antigenantibody reactions with the high resolution of gel electrophoresis for the accurate and effective diagnosis of veterinary infections. It has also been used in combination with other diagnostic methods to increase their precision and efficiency in detection of diseases (Jindal and Sharma 2010). Various researches have been carried out for the effective employment of this technique to detect different chronic and asymptomatic enzootic infections such as Enzootic Bovine Leukemia caused by Bovine Leukosis Virus (BLV) through detection of the hosts humoral response produced against the viral envelop and core proteins (glycoprotein gp51 and core protein p24, respectively) (Gonzalez et al. 1999).

\section{Biosensors}

Biosensors are tools which can detect antigens, antibodies and transduce their biological interaction into quantifiable signals through technologies such as fluorimetry, resonance and/or electrochemistry. These tools can read even the slightest variations but need highly skilled personnel to interpret the results. Moreover, the equipment is very costly and have high sample processing charges (Rajeev et al. 2011; Chakraborty et al. 2014; Balamurugan et al. 2014; Sharma et al. 2015).

\section{Pen-side tests}

These are also called field tests, which means, they can be done in the field without using expensive laboratory equipment. Developed techniques include loop-mediated isothermal amplification (LAMP-replacement for thermocyclers) (Rekha et al. 2014); simple-dot ELISA, antigen-competition ELISA, immunofiltration, dipsticks and lateral flow test - these tests do not require agarosegel electrophoresis (Arun et al. 2014). These assays bear high sensitivity and specificity, are user-friendly, rapid and prove better at being economical (Balamurugan et al. 2014; Chakraborty et al. 2014; Dhama et al. 2014; Sharma et al. 2015).

\section{Metabolite-based diagnostic tools}

\section{Proteomics}

Analysis of the structure and function of proteins, along with the evaluation of various sets of proteins, expressed by the genetic makeup of different organisms under certain conditions is defined as proteomics. For the past few decades, use of proteomics in veterinary diagnostics was limited to detection and quantification of total serum protein of the infected animal through serum protein electrophoresis (SPE). This protein-based investigation included measurement of serum albumin, globulin and albumin to globulin ratio during pathogenesis. With the enhancement in technology, the field of proteomics has 
grown significantly and now involves study of protein characterization and post-translational modification. Protein characterization is mainly carried out through the use of two major mass spectroscopy (MS) platforms, including matrix-assisted laser desorption/ionization (MALDI) and electrospray ionization (ESI). Incorporation of these modified techniques has revolutionized veterinary diagnostic investigations. Proteomics have been frequently researched upon to detect various animal diseases of great economic importance, such as mastitis and other intra-mammary infections caused by Escherichia coli and Staphylococcus species. Milk from the infected animal is analyzed before and after infection, to detect differentially expressed proteins through $2 \mathrm{D}$ electrophoresis, followed by peptide sequencing or protein characterization with the help of MALDI-TOF. The presence of such unique proteins can help in the diagnosis of certain infections.

Various other animal diseases that are researched upon to be detected via proteome identification include parasitosis, respiratory and intestinal diseases of pigs, articular disorders and equine recurrent uveitis. The study of proteomes and post-translational modifications can further be applied for the identification of potential biomarkers produced during various inflammation conditions and cancerous diseases. Some pathogen specific proteins are also capable of eliciting an immune response from the host body. The detection of infection caused by such protein producing entities through identification of serum antibodies provides a rather sensitive and specific means of disease diagnosis. This is carried out via gelbased and gel free techniques (Gowda et al. 2008; Jindal and Sharma 2010; Ceciliani et al. 2014).

\section{Nanotechnology}

According to the National Science and Technology Council of United States of America, nanotechnology has been defined as "research and development (R\&D) aimed at understanding and working with -seeing, measuring, and manipulating matter at the atomic, molecular and supra-molecular levels. This correlates to length scales of roughly 1 to 100 nanometers. At this scale, the physical, chemical and biological properties of materials differ fundamentally and often unexpectedly from those of the corresponding bulk materials." Veterinary diagnostics and treatment strategies have been greatly enhanced through the application of nanotechnology, since it carries the capability of early identification and eradication of the disease-causing pathogen. This technology has been applied in the diagnosis of several animal pathogens including Respiratory Syncytial Virus both in vitro and in vivo through nanoparticleconjugated monoclonal antibodies. It is also used for early detection of several cancer markers. This technique has proved to be very sensitive and accurate, and a great deal of research is being carried out for studying its use in the detection of various animal diseases (Scott 2007; Num and Useh 2013).
Comparative isoenzyme analysis

Isoenzyme analysis is a direct biochemical assay based on the principle that different isoforms of intracellular enzymes, such as lactate dehydrogenase, glucose-6phosphate dehydrogenase, purine nucleoside phosphorylase and malate dehydrogenase, possess different molecular structure but similar substrate specificity. When run on agarose gel electrophoresis, these enzymatic isoforms show variation in banding patterns and migration distances relative to one another. The interpretation of the isoenzyme data helps in the direct testing for the presence of various parasites infecting the host population (Drexler 2000; Zarlenga and Higgins 2001).

\section{Prevention and Treatment of diseases}

Prevention is the procedure of saving high risk animals by treating in a manner that prevents the occurrence of diseases. Treatment begins when animals show signs and symptoms of a disease. Control of disease is to prevent the transmission of already occurred diseases. The major methods adopted are diet supplementation, use of preand pro-biotics (both have been discussed under animal nutrition) and vaccination, which has been discussed below.

\section{Vaccination}

Vaccination is an effective way to control and reduce occurrence of a disease in animals and is an important factor in maintenance of animal welfare and health. Vaccines are biological preparations which help with developing immunity against disease causing microorganisms. Today various vaccines are available against many diseases whether they are endemic or exotic in nature. The several types of vaccines can be generally categorized either as non-living vaccines or modifiedliving vaccines, as shown in Figure 13. Farm animals include different species, thus, a wide range of diseases can be included in this respect. Examples include the eradication of rinderpest - a global disease of livestock in 2011 and control of other diseases like the blue tongue disease and bovine viral diarrhea etc. One most top listed concern associated with high morbidity and mortality rates is the prevalence of food-borne diseases (WHO 2015). Microorganisms like Trichinella spiralis, Taenia solium, Cryptosporidium spp., Toxoplasma gondii, and Echinococcus granulosus are top ranking foodborne parasites which are known to affect farm animals and, therefore, enter the food chain. Vaccines which contain live causative agent tend to be more immunogenic than killed or derived vaccines because they can grow and spread, consequently stimulating the immune system in an optimal fashion. Live vaccines cause the infected cells to process the microbial antigens and elicit type-1 response (dominated by cytotoxic $\mathrm{T}$ cells). Non-living vaccines consist of killed whole organism or purified antigens which stimulate type-2 response (dominated by 
antibodies). Type-2 response does not provide optimal protection and usually requires help of adjuvants, such as ethylene oxide, ethyleneimine, formaldehyde, betapropiolactone and acetylethyleneimine (Tizard 2020).

While designing a live attenuated vaccine, the level of attenuation stands critical to efficacy of the vaccine i.e., under-attenuation will result in reversion to virulence, whereas over-attenuation will result in an ineffective vaccine. The traditional method of maintaining prolonged tissue cultures can here be considered a primitive form of genetic engineering to carry out microbial attenuation and perform rigorous attenuation-to-reversion studies. This method is mostly famous for viruses; bacterial genomes are too large to manipulate in such a manner. Brucella strain 19 and Sterne strain of anthrax are two most obvious examples of bacterial vaccines developed through tissue culture technique. In extremely rare circumstances, a virulent organism may also be used as a vaccine. This approach is currently only applicable in cases of contagious ecthyma (sore mouth) of sheep, where dried and infected scab material is rubbed into scratches made on inner thighs to cause local infection and trigger immune system. Another simple method of using virulent microorganism for vaccination is to cold-attenuate virulent vaccine virus (i.e. virus adapted to grow at temperature approximately 1o degrees lower than normal body temperature); once administered intranasally, it will grow in the upper-respiratory tract but not spread in the warmer lower tract or organs, thus, causing local infection. Virulent organisms can also be genetically modified to irreversibly attenuate them. This is done by deleting the genes associated with virulence; this approach was first used in swine (against Ausjeszky disease herpesvirus). Antigens encoded genes of the causative agent can also be inserted into an avirulent organism, called a 'vector', in place of its genes instead. Large DNA-viruses are the most widely used vectors for development of vectored vaccines. These vaccines are safe to administer, are effective and stable in the absence of adjuvants, and can be used for mass vaccination purposes (Tizard 2020).

Of the many vaccine platforms and designs, whole-killed vaccines are economical to produce; however, these do contain various components which play no contributing role towards triggering protective immunity and may sometimes carry toxins too. The alternative to these are subunit vaccines, which only consist of the specific critical protective antigens, for example the pili of enteropathogenic E.coli and purified (inactivated) tetanus toxin - can be separately used as vaccines. The process of isolating and purifying specific antigens is cost-intensive and hence might not be a suitable approach in every case. For otherwise cases, the production of antigens through gene cloning may surface as a better, cost-effective option; these elicit effective antigenicity and function as effectual toxoids. Viral antigen genes can also be cloned in plants which constitute livestock feed; these plants transfer high concentration of antigens to the animals simply through feeding. This method has been successfully applied against Newcastle disease virus and transmissible gastro-

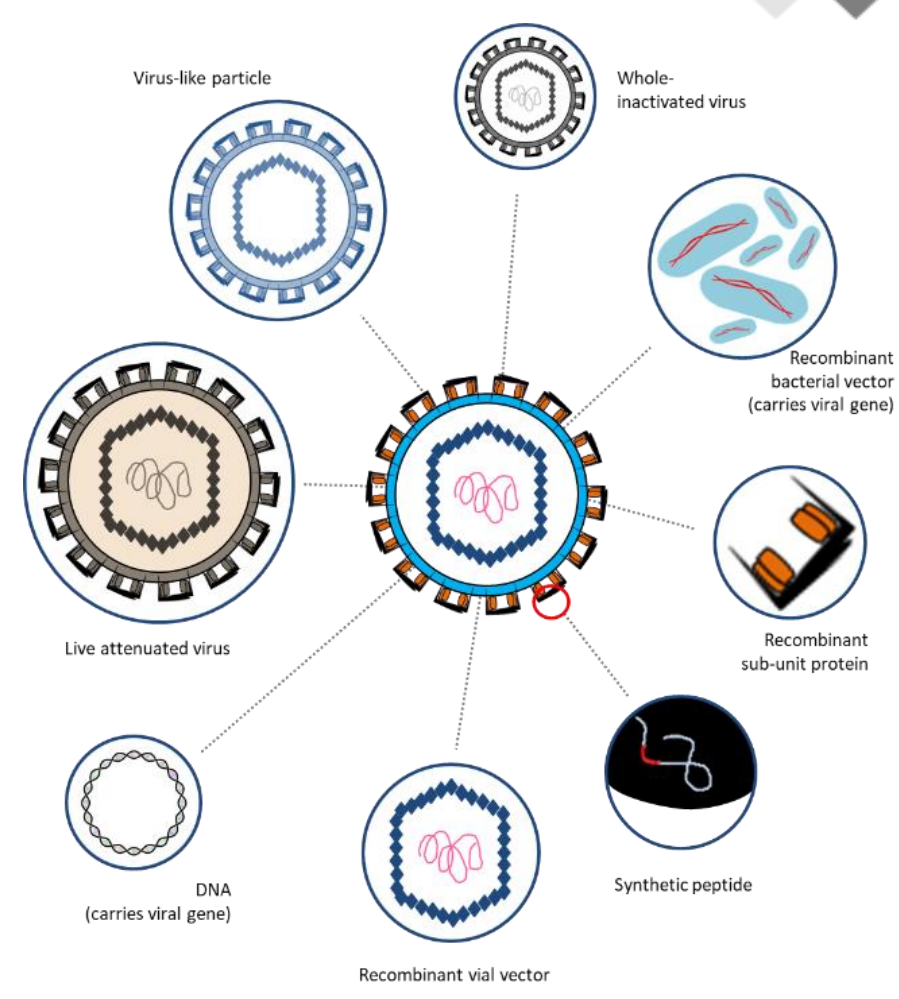

Figure 13: Types of vaccines for animals.

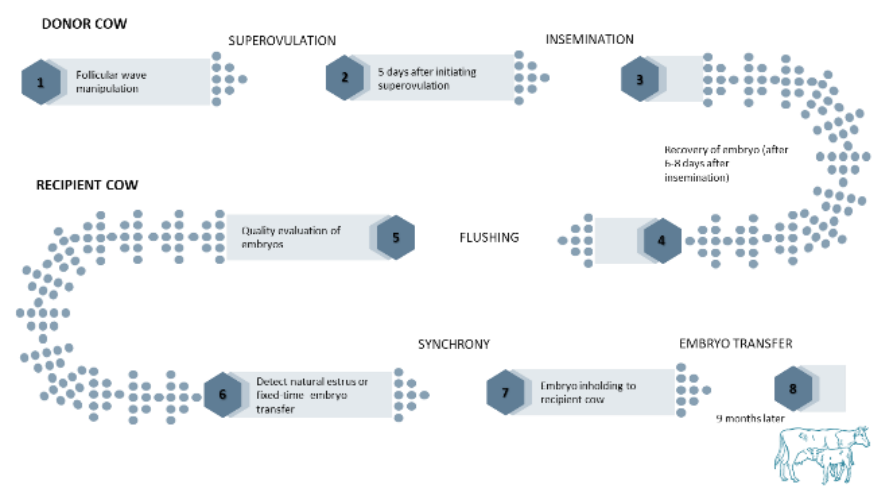

Figure 14: The process flowchart of Embryo transplantation.

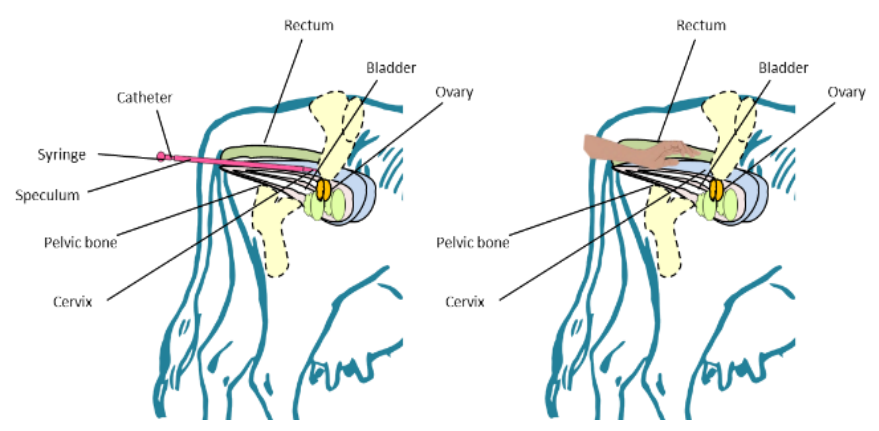

Figure 15: AI for cows. (Left) Speculum method, the semen is deposited through the cervix by vaginal insertion of a speculum; (Right) Recto-vaginal technique, the inseminator holds the cervix through the rectum to guide the inseminating instrument into the opening of the cervix, and then deposits the semen through the inseminating instrument.

enteritis virus. Likewise, viral structural protein can be produced through recombinant technology and assembled into virus-like particles (VLPs). These vaccines act as 
potent immunogens in the absence of adjuvants. Similarly, ghost-bacterial vaccines can also be developed in this manner; these are bacterial cells void of their genetic material, thus, only carry surface structures. DNA segments, which are responsible for encoding viral antigens, can also be inserted into a bacterial plasmid (vector) and injected directly into host cells (transfection). The plasmid uses host cell machinery to transcribe and translate the vaccine proteins, which are then expressed by the host cell with major histocompatibility complex class I molecules triggering type-1 and type-2 immune responses (Tizard 2020).

Therefore, the development of veterinary vaccines against known viruses and parasites contribute significantly towards animal health and well-being (Sander et al. 2020). However, as per the current progress of vaccine development, more coordinated efforts are required to increase public compression and acceptance regarding vaccination, and address the various cultural, economic, and political actors which carry influence on disease eradication strategies.

\section{Immunotherapy}

Immunotherapy is an emerging way of treating diseases by suppressing or activating immune response in both animals and humans. Immunotherapies that act by activating or amplifying immune system are categorized as activation immunotherapies. Suppression immunotherapies act by suppressing immune response. It involves partial or complete elimination of immune system by chemotherapy. But now it is considered to boost the immune system and protect it. Most useful immune therapy used till now is monoclonal antibodies directed against checkpoint molecules and lymphoma antigens. Blockage of these pathways stimulates cytotoxic ability of $\mathrm{T}$ lymphocytes, and also activates immune system responses. Cytokine release and antigen presentation can be activated. Cellular immunotherapy is a type in which $\mathrm{T}$ cells are given a chance to fight against disease. Feline asthma has been treated with subcutaneous immunotherapy. Use of monoclonal antibodies is the newer way of immunotherapy these days. Infected animals are given monoclonal antibodies that are specific to some viral antigen or tumor antigen and can neutralize or kill them. These types of antibodies can be administered alone or with some arsenic like toxic compounds. This type of therapy is beneficial, as it can kill the virus or tumor found anywhere in the body that have the particular antigen. This type of treatment makes viral or tumor therapy possible economically and plays an important role in maintaining animal health. This type of therapy is more useful than irradiation or chemotherapy, as it produces local reaction and destroys tumor or virus by the presence of specific antigen.

In veterinary medicine, anti-idiotypic vaccine is another application of monoclonal antibodies. According to this therapy, monoclonal antibody made against idiotype of another monoclonal antibody acts as vaccine. For example, monoclonal antibodies are made against neutralization site of swine causing agent that is pseudorabies virus. Then, another monoclonal antibody against first antigen binding cleft monoclonal antibody is made. This anti-idiotypic antibody is administered to pig and it binds to B-lymphocytes that carries antigen of pseudorabies virus and then antibodies are made that neutralize pseudo-rabies virus. The anti-idiotypic vaccines are useful as majority of animal vaccines are live; they can divide and cause disease themselves. Monoclonal antibodies are beneficial, as they can be used to diagnose animal diseases. Series of sensitive and quick immune assays identify the disease, and the treatment of animals can be started immediately. Monoclonal antibodies are also used in dipstick techniques. Use of monoclonal antibodies in dipstick methods allows information about level of pesticides or mycotoxins contaminating feed. It is also beneficial in checking whether meat, milk or poultry products are contaminated with antibiotics, harmful drug residues or carcinogens. Future, detection of any organism or substance involves the use of monoclonal antibodies. Monoclonal antibodies are widely used in research as well. They are used to trace synthesis of milk during lactation, purifying compounds and to study role of certain enzymes and protein in cancer. In future, monoclonal antibodies can be very beneficial for animal health.

\section{Cytokine Therapy}

Cytokines are regulatory glycoproteins that are small in size. They are secreted by cells of immune system and regulate, as well as boost, immunity. They are produced as messenger by immune cells to attack an entering microorganism. They also communicate with other types of cells of immune system. Cytokines are either membrane bound or secreted, and regulate homeostasis of immune system by acting as intracellular mediators. Cytokines attach through specific receptors to outer membrane of target cell. They induce a cascade of reactions and alter gene expression by signal-transduction pathway activation. This pathway plays a role in both adaptive and innate immunity. Cytokines regulate immune response by inhibiting or stimulating differentiation, proliferation and trafficking of lymphocytes. They also play a role in biological activities i.e. hematopoiesis, adaptive and innate immunity, regulation and development of humoral and cellular immune responses, control of cellular differentiation, proliferation and inflammatory response. They show characteristics of redundancy, pleiotropy, antagonism, synergy, and cascade induction, which altogether regulate cellular functions. They also play an important role in healing of wounds.

Cytokine therapy is now a new method of treatment. Recombinant or purified cytokines are administered during therapy. Drugs are also administered which inhibit harmful effects of increased production of endogenous cytokines. Cytokine-based therapies include colony stimulating factors, hematopoietic growth factors and interferons for progression and stimulation of various processes. Cytokine antagonists have intense effects on inflammatory disorders treatment, such as tumor necrosis 
factor inhibitors. Interferons are effective agents used against infectious diseases of horses and cattle. Interferons are antiviral agents, used in controlling viral infections when adaptive immunity is absent. They also act against intracellular bacterial species. They are used both for prevention, as well as cure, of viral infection of animals or act as adjuvant in treatment to decrease manifestations of disease, so that quality of life is improved. Cytokines are used as adjunctive immunomodulators and play important role in treatment of infectious diseases. Ribavirin and PEG-ylated interferons used for hepatitis C and nucleoside analogs and recombinant interferons used for hepatitis B virus are the most common example of cytokine treatment. They induce Th1 immunity. They can also be used in vaccines as mucosal adjuvants such as IL12. IL-15, and IL-7. Granulocyte stimulating factor, macrophage inflammatory proteins and monocyte chemotactic proteins along with cytokines are used in vaccines. The activity of cytokine therapy depends on three factors that are:

- Cytokine or receptor signaling

- Cytokine or receptor attaching affinity

- Receptor or cytokine endocytic transferring dynamics Interferons and IL-2 enhance action of T lymphocytes in removing Eimeria in birds, which is a Coccidian parasite. These cytokines used with newly designed vaccines can control experimental Coccidiosis infection in birds. TNF $\alpha$ and gamma interferon are together used in the treatment of mastitis in bovines.

\section{Nanotechnology}

Nanotechnology is one of the important factors involved in treatment of animal diseases. Nanotechnology is the field of small things, with chemical and physical modifications in their structure, and higher solubility and reactivity. Natural nano particles are derived from different methods, for example nano-propolis is beneficial for veterinary medicine in relation to food production, health and performance. Nano propolis is propolis particles in nano-size tied together; these are made effective by changing propolis size through different techniques, yet they maintain their properties. Propolis particles show many activities, such as antifungal, antioxidant, anti-inflammatory and anti-cancer. Free form propolis consumption results in low solubility, low absorption, low bioavailability, and untargeted release and restrict the benefits provided by use of non-free nanopropolis. To obtain nano-propolis, different nanoencapsulation methods are used. Due to small size, absorption of nano-propolis is quite easy, and they are easily delivered outside specific barriers, such as subcellular organelles, skin, brain, blood, mucus, eye, extracellular and cellular matric and placenta. Nanopropolis has better antifungal and antibacterial activity than propolis. Nanotechnology is used in human, as well as animal, health, such as the use of nano-propolis in animal nutrition and health. Nanotechnology denotes the developing technology in atomic, molecular and macromolecular fields. It is beneficial to animal health due to its high biodegradability and high bioavailability properties and gives scientific benefit with its specific and rapid moves. These benefits largely affect production, as well as economic losses of animals, and production of healthy feed and food. Nanotechnology devices are used in diagnosis of human, as well as animal, diseases and it's a great accomplishment in health field. Advances in nanotechnology can solve many problems of animal health. It can solve problems related to animal production, reproduction, health and maintenance of food animals.

\section{Reproductive animal biotechnology}

One of the quickest growing agricultural sectors is livestock production, comprising more than third of the total agricultural GDP. This is a consequence of increasing global food protein demand, which is shifting from plant protein to animal protein. As discussed previously, biotechnological advancements potentiate animal productivity through improving three factors; improved nutrition, improved health and via increasing animal reproduction through technologies, such as multiple ovulation and embryo transfer (MOET), artificial insemination (AI), sperm sexing, In vitro embryo production, embryo splitting, embryonic stem cell technology and lastly by successfully conserving resources of animal genetics through marker-assisted selection (MAS) techniques, which serve various applications including heritability determination, product traceability and trait improvement. The objective of using these biotechnologies, in general, is to improve reproductive efficiency of livestock.

\section{Multiple ovulation and embryo transfer (MOET)}

In this process, reproduction is assisted through embryo placement into surrogate uterus in order to establish pregnancy. MOET is done in three steps: (i) hormone stimulated superovulation in selected females, (ii) collection of developed embryos, and (iii) transfer of healthy embryos to healthy female recipients (Figure 14). This technique helps in increasing the number of successful pregnancies and thereby the number of calves produced. As embryos are pre-evaluated (on the basis of their quality) and only selected ones are transferred, this enables preservation and conservation of breeds, maintaining a disease-free herd, and enabling rapid multiplication of superior female breeding stock (Tappa et al. 1994). Moreover, the developed embryos can be transferred across greater distances, making livestock transport significantly economical; an estimated total of 1000 goat embryos, 68,0oo sheep embryos and 550,000 bovine embryos were transferred worldwide in year 2004, as reported by the International Embryo Transfer Society (IETS) (Thibier 2005). 


\section{Artifical insemination (AI)}

This is one of the earliest reproductive technologies through which sperms collected (cryopreserved) from an elite male are planted into the uterus of an elite female without the process of mating (Figure 15). AI remains to be the most simple, economical, and successful assistedreproductive technology (Jacquelyn and Laura 2008). This technique reduces the transmission probability of venereal diseases, lowers the need of maintaining breeding males, is cost-effective, and facilitates canonical recording of pedigrees (Wilmut et al. 1997).

\section{Sperm sexing}

This technology is a derivation of AI with sexed sperms. A tremendous number of calves have been produced through sperm sexing and when used in dairy cows, it is reported to result in a ratio match of $81 \%$ (Said et al. 2005; Agung et al. 2016).

\section{In vitro fertilization}

This process is used when conditions, such as marginal semen quantity and quality, non-responsive ovaries, blocked female reproductive system or presence of an infection in the tubular genitalia, are encountered. Hereby, fertilization is carried out in vitro and the fertilized egg is then introduced into the uterus to establish pregnancy. This system ensures that the resulting zygote is competent for maturation and development in the body. However, the high cost of this approach limits its wide and regularly adopted use in livestock industry (Chang 1959; Bearden and Faquay 2004).

\section{Embryo splitting}

With this technology, twins or multiples can be formed through artificial splitting of an embryo. The microsurgically separated embryos are genetically identical; thus this method is a duplication of the natural process of monozygotic twins (Said et al. 2020).

\section{Embryonic stem cell technology}

Stem cells elicit pluripotency and can thereby be manipulated to change their behavior. In this process, stem cells driven from undifferentiated inner cell mass of embryo are harvested from the donor animal and are manipulated in vitro to change their behavior and are maintained till the inner cell mass forms egg-like cylindrical structure (Evans and Kaufman 1981).

\section{Marker-assisted selection (MAS)}

The discovery of DNA sequences (molecular markers) has opened the possibility of improving traits, determining heritability of traits and catering product traceability. Various genetic diseases or defects can be detected in livestock using these molecular markers. Thus, it can help trace genetic changes and their manifestations; the animals carrying the defect can then be culled from the breeding program to prevent defective genes from getting transferred ahead (Cunningham and Meghan 2001; Womack 2005). These markers are also used to identify livestock parentage and their products (Cunningham and Meghan 2001) and can also be used to select animals which express introgressed genes.

\section{Future implications of biotechnology in livestock industry}

With the enormous scale of advancement in livestock biotechnology, the new possibilities introduced for research opportunities will help revolutionize livestock sector and be able to cater the concerns regarding food insecurity in developing and undeveloped countries. As for the growing population, these advancements allow improving health and production potential of animals at as early as the stage of fetus development. Moreover, these techniques will also contribute to lower livestock environment footprint.

\section{REFERENCES}

Aachary AA and Prapulla SG, 2011. Xylooligosaccharides (XOS) as an emerging prebiotic: Microbial synthesis, utilization, structural characterization, bioactive properties and applications. Comprehensive Reviews in Food Science and Food Safety 10: Article \# 1.

Ageitos JM et al., 2017. Antimicrobial peptides (amps): Ancient compounds that represent novel weapons in the fight against bacteria. Biochemical Pharmacology 133: 117-138.

Agung PP et al., 2016. Myostatin gene analysis in the first generation of the Belgian Blue cattle in Indonesia. Journal of the Indonesian Tropical Animal Agriculture 41: 13-20.

Ahasan ASML et al., 2015. The beneficial role of probiotics in monogastric animal nutrition and health. Journal of Dairy, Veterinary and Animal Research 2: 116-132.

Alakomi HL et al., 2003. Effect of EDTA on Salmonella enterica serovar Typhimurium involves a component not assignable to lipopolysaccharide release. Microbiology 149: 2015-2021.

Alexandratos N and Bruinsma J, 2012. World Agriculture towards 2030/2050: the 2012 revision. World Agriculture. Retrieved from www.fao.org/economic/ esa.

Arikan OA et al., 2009. Management of antibiotic residues from agricultural sources: Use of composting to reduce chlortetracycline residues in beef manure from treated animals. Journal of Hazardous Materials 164: 483-489.

Arun TR et al., 2014. Development of a gold nanoparticles based lateral flow assay for rapid diagnosis of Contagious Agalactia in goats. Asian Journal of Animal and Veterinary Advances 9: 405-413. 
Aslam F et al., 2020. Production of commercially important enzymes from Bacillus licheniformis KIBGE-IB3 using date fruit wastes as substrates. Journal of Genetic Engineering and Biotechnology 18: 1-7.

Aust MO et al., 2008. Distribution of sulfamethazine, chlortetracycline and tylosin in manureand soil of Canadian feedlots after subtherapeutic use in cattle. Environmental Pollution 156: 1243-1251.

Bahar AA and Ren D, 2013. Antimicrobial peptides. Pharmaceuticals 6: Article \# 12.

Balamurugan V et al., 2014. Diagnosis and control of Peste des petits ruminants: A comprehensive review. Virus Disease 25: 39-56.

Basu A et al., 2015. Modeling of enzymatic production of Isomaltooligosaccharides: A mechanistic approach. Catalysis Science \& Technology 5: 2945-2958.

Bearden HJ et al., 2004. Semen evaluation. In: Bearden HJ and Fuquay JW (editors). Applied Animal Reproduction. Prentice Hall, Upper Saddle River, New Jersey, USA.

Beauchemin KA et al., 2019. Recombinant fibrolytic feed enzymes and ammonia fibre expansion (AFEX) pretreatment of crop residues to improve fibre degradability in cattle. Animal Feed Science and Technology 256: Article \# 114260.

Bedford MR, 1996. The effect of enzymes on digestion. Journal of Applied Poultry Research, 5: 370-378.

Belov A et al., 2020. Development of equipment for producing feed mixtures with nanoparticles of scarce micronutrients. Engineering for Rural Development 20: 1757-1762.

Bengmark S and Martindale R, 2005. Prebiotics and synbiotics in clinical medicine. Nutrition in Clinical Practice 20: 244-261.

Bhat MK, 200o. Cellulases and related enzymes in biotechnology. Biotechnology Advances 18: 355-383.

Bohning J and Morris JT, 1999. The "Marker Degradation" and creation of the Mexican steroid hormone industry. Olofson RA, Gortler LB (editors). American Chemical Society; pp: 1-8.

Borroto CG, 2009. Biotechnology and its application to veterinary science. Compendium of technical items presented to the International Committee or to Regional Commissions of the OIE 2008: 231-250.

Brienzo $\mathrm{M}$ et al., 2010. Xylooligosaccharides production from alkali-pretreated sugarcane bagasse using xylanases from Thermoascus aurantiacus. Applied Biochemistry Biotechnology 162: 1195-1205.

Brown $\mathrm{K}$ et al., 2017. Antimicrobial growth promoter use in livestock: A requirement to understand their modes of action to develop effective alternatives. International Journal of Antimicrobial Agents 49: 1224.

Broz J and Firgg M, 1986. Effects of beta-glucanase on the feeding value of broiler diets based on barley or oats. Archiv für Geflügelkunde 50: 41-47.

Buchholz K and Bornscheuer UT, 2017. Enzyme technology: History and current trends. In: Yoshida T (editor). Applied Bioengineering: Innovations and
Future Directions, First Edition. Wiley-VCH Verlag GmbH \& Co. KGaA, Weinheim, Germany; pp: 13-46.

Butaye $\mathrm{P}$ et al., 2003. Antimicrobial growth promoters used in animal feed: Effects of less well known antibiotics on Gram-positive bacteria. Clinical Microbiology Reviews Journal 16: 175-188.

Campbell GL and Bedford MR, 1992. Enzyme applications for monogastrics feeds: A review. Canadian Journal of Animal Science 72: 449-456.

Campbell GL et al., 1989. Genotypic and environmental differences in extract viscosity of barley and their relationship to its nutritive value for broiler chickens. Animal Feed Science and Technology 26: 221-230.

Cano-Flores A et al., 2020. Biotransformation of steroids using different micro-organisms. In: Chemistry and Biological Activity of Steroids. Taylor \& Francis Online Mexico.

Ceciliani F et al., 2014. Proteomics in veterinary medicine: Applications and trends in disease pathogenesis and diagnostics. Veterinary pathology 51: 351-362.

Cencic A and Chingwaru W, 2010. The role of functional foods, nutraceuticals, and food supplements in intestinal health. Nutrients 2: Article \# 6.

Chakraborty S et al., 2014. Advances in diagnosis of respiratory diseases of small ruminants. Veterinary Medicine International 2014: 1- 16.

Chang MC, 1959. Fertilization of rabbit ova in vitro. Nature 184: 466-467.

Chattopadhyay MK, 2014. Use of antibiotics as feed additives: A burning question. Frontiers in Microbiology 5: 1- 3 .

Chen CW et al., 2003. Synthesis of galactooligosaccharides and transgalactosylation modeling in reverse micelles. Enzyme and Microbial Technology 33: 497-507.

Chen J et al., 2011. Biochemical characterization of an intracellular 6G-fructofuranosidase from Xanthophyllomyces dendrorhous and its use in production of neo-fructooligosaccharides (neo-FOSs). Bioresource Technology 102: 1715-1721.

Cho JH et al., 2011. Probiotics as a dietary additive for pigs. Journal of Animal and Veterinary Advances 10: 21272134.

Chockchaisawasdee S et al., 2005. Synthesis of galactooligosaccharide from lactose using beta-galactosidase from Kluyveromyces lactis: Studies on batch and continuous UF membrane-fitted bioreactors. Biotechnology and Bioengineering 89: 434-443.

Choi SC et al., 2013. An antimicrobial peptide-A3: Effects on growth performance, nutrient retention, intestinal and faecal microflora and intestinal morphology of broilers. British Poultry Science 54: 738-746.

Clark MF et al., 1986. ELISA techniques. Methods in Enzymology 118: 742-766.

Classen HL, 1993. Microbial enzyme use in feed. In: Muirhead S, (editor). Direct-fed Microbial, Enzyme and Forage Additive Compendium, Vol. 1, The Miller Publishing Co, Minnetonka, Minn., USA, pp: 23-26.

Coates ME et al., 1963. A comparison of the growth of chicks in the Gustafsson germ-free apparatus and in a 
conventional environment, with and without dietary supplements of penicillin. British Journal of Nutrition 17: 141-150.

Colbert WE et al., 1991. $\beta$-adrenoceptor profile of ractopamine $\mathrm{HCl}$ in isolated smooth and cardiac muscle tissues of rat and guinea-pig. Journal of Pharmacy and Pharmacology 43: 844-847.

Crittenden R and Playne MJ, 20o9. Prebiotics. In: Lee YK, Salminen S (editors). Handbook of Probiotics and Prebiotics. Hoboken, New Jersey: Wiley, pp: 535-561.

Cunningham EP and Meghen CM, 2001. Biological identification systems: Genetic markers. Scientific and Technical Review of the Office International des Epizooties 20: 491-499.

Cutler SA et al., 2007. Dietary inclusion of colicin e1 is effective in preventing postweaning diarrhea caused by F18-positive Escherichia coli in pigs. Antimicrobial Agents and Chemotherapy 51: 3830-3835.

Dai S and Long Y, 2015. Genotyping analysis using an RFLP assay. In: Plant Genotyping, Springer pp: 91-99.

Dhama $K$ et al., 2014. Loop-mediated isothermal amplification of DNA (LAMP) - a new diagnostic tool lights the world of diagnosis of animal and human pathogens: A review. Pakistan Journal of Biological Sciences 17: 151-166.

Dibner JJ and Richards JD, 2005. Antibiotic growth promoters in agriculture: History and mode of action. Poultry Science 84: 634-643.

Dilokpimol A et al., 2011. Enzymatic synthesis of $ß$ xylosyl-oligosaccharides by transxylosylation using two $ß$-xylosidases of glycoside hydrolase family 3 from Aspergillus nidulans FGSC A4. Carbohydrate Research 346: 421-429.

Doukyu $\mathrm{N}$ et al., 2007. Purification and characterization of a maltooligosaccharide forming amylase that improves product selectivity in water miscible organic solvents, from dimethylsulfoxide-tolerant Brachybacterium sp. strain LB25. Extremophiles 11: 781-788.

Drexler HG, 200o. The Leukemia-Lymphoma Cell Line Factsbook. Academic Press.

Duncan GW et al., 1964. Biologic effects of melengestrol acetate. Fertility and Sterility 15: 419-432.

Etherton TD et al., 1993. Recombinant bovine and porcine somatotropin: Safety and benefits of these biotechnologies. Journal of the American Diabetic Association 93: 177-18o.

Evans M and Kaufman M, 1981. Establishment in culture of pluripotent cells from mouse embryos. Nature 292: 154-156.

FDA, 2021. Steroid hormone implants used for growth in food-producing animals. Content current as of $13^{\text {th }}$ May 2021. (Accessed on 3oth may 2021).

FEFANA, 2005. Probiotics in Animal Nutrition. EU Feed Additives and Premixtures Association.

Fernandez P and Cabral JMS, 2010. Steroid bioconversion. In: Flickinger $\mathrm{M}$ (editor). Encyclopedia of Industrial Biotechnology: Bioprocess, Bioseparation, and Cell Technology. John Wiley \& Sons, Inc., New York, USA; pp: 1-32.

Fernandez $\mathrm{P}$ et al., 2003. Microbial conversion of steroid compounds: Recent developments. Enzyme and Microbial Technology 32: 688-705.

Filer K, 2003. Industrial production of enzymes for the feed industry. In: New Horizons in Biotechnology. Roussos S. et al. (editors). Kluwer Academic Publishers; pp: 1-16.

Fisher GEJ, 2008. Micronutrients and animal nutrition and the link between the application of micronutrients to crops and animal health. Turkish Journal of Agriculture and Forestry 32: 221-233.

Fuller R, 1989. Probiotics in man and animals. A review. Journal of Applied Bacteriology 66:365-378.

Galyean ML et al., 200o. Effects of live cultures of Lactobacillus acidophilus (Strains 45 and 51) and Propionibacterium freudenreichii PF-24 on performance and carcass characteristics of finishing beef steers. Burnett Center Internet Progress Report, Texas Tech University, Lubbock.

Ganz T, 2002. Antimicrobial polypeptides in host defense of the respiratory tract. Journal of Clinical Investigation 109: 693-697.

Gao L et al., 2012. Occurrence of antibiotics in eight sewage treatment plants in Beijing, China. Chemosphere 86: 665-671.

Garrote G and Parajo JC, 2002. Non-isothermal autohydrolysis of eucalyptus wood. Wood Science Technology 36: 111-123.

Gibson GR and Roberfroid MB, 1995. Dietary modulation of the human colon microbiota: Introducing the concept of prebiotics. Journal of Nutrition 125: 14011412.

Gonzalez ET et al., 1999. Evaluation of Western Blotting for the diagnosis of enzootic bovine leukemia. Arquivo Brasileiro de Medicina Veterinária e Zootecnia 51: 299-305.

Gowda GN et al., 2008. Metabolomics-based methods for early disease diagnostics. Expert Review of Molecular Diagnostics 8: 617-633.

Graham JP et al., 2007. Growth promoting antibiotics in food animal production: An economic analysis. Public Health Reports 122: 79-87.

Grajek W and Sip A, 2004. Biological fixation food with utilization of lactic acid bacteria metabolites In: Libudzisz Z, Walczak P, Bardowski J (editors). Lactic Acid Bacteria. Classification, Metabolism, Genetiics, Application. Politechnikalodzka, pp: 103-197.

Guarner F, 2007. Prebiotics in inflammatory bowel diseases. British Journal of Nutrition 98(Supplment 1): $\mathrm{S} 85-\mathrm{S} 89$.

Guo FC et al., 2004a. Effect of a Chinese herb medicine formulation, as an alternative for antibiotics, on performance of broilers. British Poultry Science 45: 793-797.

Guo FC et al., 2004b. Effects of mushroom and herb polysaccharides, as alternatives for an antibiotic, on growth performance of broilers. British Poultry Science 45: 684-694. 
Halling-Sorensen B et al., 2001. Worst case estimations of predicted environmental soil concentrations (PEC) of selected veterinary antibiotics and residues used in Danish agriculture. In: Kummerer K, (editor). Pharmaceuticals in the Environment. Springer Verlag, Berlin, Germany; pp: 143-157.

Hesselman K and Åman P, 1986. The effect of $\beta$-glucanase on the utilization of starch and nitrogen by broiler chickens fed on barley of low or high viscosity. Animal Feed Science and Technology 15: 83-93.

Hsu CA et al., 2007. Enzymatic production of galactooligosaccharides by beta-galactosidase from Bifidobacterium longum BCRC 15708. Journal of Agricultural and Food Chemistry 55: 2225-2230.

Huang YC et al., 2010. Heterologous expression of thermostable acetylxylan esterase gene from Thermobifida fusca and its synergistic action with xylanase for the production of xylooligosaccharides. Biochemical and Biophysical Research Communications 400: 718-723.

Hughes $\mathrm{P}$ and Heritage J, 2002. Antibiotic growthpromoters in food animals. Food and Agriculture Organization, retrieved from: http://www.fao.org/3/y5159e/y5159eo8.htm

Hunter MC et al., 2017. Agriculture in 2050: Recalibrating targets for sustainable intensification. BioScience 67: 386-391.

Idowu $F$ et al., 2010. Antimicrobial screening of commercial eggs and determination of tetracycline residue using two microbiological methods. International Journal of Poultry Science 9: 959-962.

Jacquelyn GB and Laura JB, 2008. Microbiology: Principles and Explorations, 7th Edition, John wiley and Sons, New Jersey, USA.

Ji ES et al., 2005. Galacto-oligosaccharide production by a thermostable recombinant $\beta$-galactosidase from Thermotoga maritima. World Journal of Microbiology and Biotechnology 21: 759-764.

Jindal SK and Sharma MC, 2010. Biotechnology in Animal Health and Production. New India Publishing India.

Jun $\mathrm{H}$ et al., 2009. Functional characterization of a recombinant thermostable xylanase from Pichia pastoris: A hybrid enzyme being suitable for xylooligosaccharides production. Biochemical Engineering Journal 48: 87-92.

Jung HG et al., 2004. Forage fiber digestibility: Measurement, variability, and impact. Proceedings of the 65th Minnesota Nutrition Conference, St. Paul, MN. University of Minnesota, Minneapolis, MN, pp: $105^{-125}$.

Kahi A and Rewe T, 20o8. Biotechnology in livestock production: Overview of possibilities for Africa. African Journal of Biotechnology 7: 4984-4991.

Kawaguti HY et al., 2011. Immobilization of Erwinia sp. D12 cells in alginate-gelatin matrix and conversion of sucrose into isomaltulose using response surface methodology. Enzyme Research 2011: Article \# 791269.

Khadem A et al., 2014. Growth promotion in broilers by both oxytetracycline and Macleaya cordata extract is based on their anti-inflammatory properties. British
Journal of Nutrition 112: 1110-1118.

Kim M and Schrenk D, 2012. Chemical contamination of red meat. In: Schrenk D (editor). Chemical Contaminants and Residues in Food. Woodhead Publishing Series in Food Safety, Technology and Nutrition; pp: 447-467.

Kornegay ET, 2001. Digestion of phosphorus and other nutrients: The role of phytases and factors influencing their activity. In: Bedford MR, Partridge GG (editors). Enzymes in Farm Animal Nutrition. CABI Publishing, London, UK; pp: 237-271.

Kubik $C$ et al., 2004. Immobilization of dextransucrase and its use with soluble dextranase for glucooligosaccharides synthesis. Enzyme and Microbial Technology 34: 555-56o.

Kwon SI et al., 2011. Applicability of the Charm II system for monitoring antibiotic residues in manure-based composts. Waste Management 31: 39-44.

Lee HS et al., 2002. Cooperative action of alpha glucanotransferase and maltogenic amylase for an improved process of isomaltooligosaccharide (IMO) production. Journal of Agriculture and Food Chemistry 50: 2812-2817.

Lee $\mathrm{SH}$ et al., 2014. Effects of dietary supplementation with Bacillus subtilis LS 1-2 fermentation biomass on growth performance, nutrient digestibility, cecal microbiota and intestinal morphology of weanling pig. Animal Feed Science and Technology 188: 102-110.

Lei X et al., 2015. Effect of Bacillus amyloliquefaciensbased direct-fed microbial on performance, nutrient utilization, intestinal morphology and cecal microflora in broiler chickens. Asian-Australasian Journal of Animal Sciences 28: 239-246.

Li Z et al., 2008. Production of non-monosaccharide and high-purity galactooligosaccharides by immobilized enzyme catalysis and fermentation with immobilized yeast cells. Process Biochemistry 43: 896-899.

$\mathrm{Li} \mathrm{Z}$ et al., 2018. Antimicrobial resistance in livestock: Antimicrobial peptides provide a new solution for a growing challenge. Animal Frontiers 8: 21-29.

Liu X et al., 2014. Ractopamine, a livestock feed additive, is a full agonist at trace amine-associated receptor 1. Journal of Pharmacology and Experimental Therapeutics 350: 124-129.

Lu L et al., 2007. A novel beta-galactosidase capable of glycosyl transfer from Enterobacter agglomerans B1. Biochemical and Biophysical Research Communications 356: 78-84.

Marchant-Forde JN et al., 2003. The effects of ractopamine on the behavior and physiology of finishing pigs. Journal of Animal Science 81: 416-422.

McDonald $\mathrm{P}$ et al., 2010. Animal Nutrition. $7^{\text {th }}$ Edition, Pearson Books Robert Wilkinson, University of Aberdeen, UK.

McKeever DJ and Rege J, 1999. Vaccines and diagnostic tools for animal health: The influence of biotechnology. Livestock Production Science 59: 257264 .

Thompson A et al., 2020. Effects of direct-fed microbial products on feedlot performance and carcass 
characteristics of feedlot steers. Open Journal of Animal Sciences 10: 2020.

Meissonnier E and Mitchell-Vigneron J, 1983. Anabolics in animal production: Public health aspects, analytical methods, and regulation symposium. OIE, Paris.

Mordor, 2021. Prebiotic ingredients market-growth, trends, covid-19 impact and forecasts (2021-2026). Available https://www.mordorintelligence.com/industryreports/prebiotics-ingredients-market

Mundra $\mathrm{P}$ et al., 2007. Application of response surface methodology to cell immobilization for the production of palatinose. Bioresource Technology 98: 2892-2896.

Mussatto SI et al., 2009. Colonization of Aspergillus japonicus on synthetic materials and application to the production of fructooligosaccharides. Carbohydrate Research 344: 795-80o.

Myers-Keith P, 1983. Applications of biotechnology to animal health and production. Biotechnology $1: 867$.

Nations U, 2017. World Population Prospects: The 2017 Revision. $\quad$ Retrieved from https://www.un.org/development/desa/publications/ world-population-prospectsthe-2017-revision.html

Naidoo K et al., 2009. Enhanced fructooligosaccharides and inulinase production by a Xanthomonas campestris pv. phaseoli KM 24 mutant. Bioprocess and Biosystems Engineering 32: 689-695.

Nakkharat $\mathrm{P}$ et al., 2006. Formation of galactooligosaccharides during lactose hydrolysis by a novel beta-galactosidase from the moderately thermophilic fungus Talaromyces thermophilus. Biotechnology Journal 1: 633-638.

Ndelekwute EK et al., 2019. Effect of dietary organic acids on nutrient digestibility, faecal moisture, digesta $\mathrm{pH}$ and viscosity of broiler chickens. MOJ Anatomy \& Physiology 6: 40-43.

Nemukula A et al., 2009. Response surface methodology: Synthesis of short chain fructooligosaccharides with a fructosyltransferase from Aspergillus aculeatus. Bioresource Technology 100: 2040-2045.

Newman RK and Newman CW, 1987. Beta-glucanase effect on the performance of broiler chicks fed covered and hulless barley isotypes having normal and waxy starch. Nutrition Reports International 36: 693699.

Nguyen TH et al., 2007. Characterization and molecular cloning of a heterodimeric beta-galactosidase from the probiotic strain Lactobacillus acidophilus R22. FEMS Microbiology Letters 269: 136-144.

Num S and Useh N, 2013. Nanotechnology applications in veterinary diagnostics and therapeutics. Sokoto Journal of Veterinary Sciences 11: 10-14.

Oba M and Allen M, 1999. Evaluation of the importance of the digestibility of NDF from forage: Effects on dry matter intake and milk yield of dairy cows. Journal of Dairy Science 82: 589-596.

Ohno A et al., 2013. Evaluation of Camellia sinensis catechins as a swine antimicrobial feed additive that does not cause antibiotic resistance. Microbes and
Environments 28: 81-86.

Olveira G and González-Molero I, 2016. An update on probiotics, prebiotics and synbiotics in clinical nutrition. Endocrinologia y Nutricion 63: 482-494.

Onishi N and Tanaka T, 1996. Purification and properties of a galacto- and gluco-oligosaccharide-producing $\beta$ glycosidase from Rhodotorula minuta IFO879. Journal of Fermentation and Bioengineering 82: 439-443.

Oscara S et al., 2007. Fructo-oligosaccharides production from sucrose by Aspergillus sp. $\mathrm{N}_{74}$ in a hybrid bioreactor. Proceedings of European Congress of Chemical Engineering (ECCE-6) Copenhagen, 16-20 September 2007.

Ostermann A et al., 2013. Leaching of veterinary antibiotics in calcareous Chinese croplands. Chemosphere 91: 928-934.

Overland $\mathrm{M}$ et al., 2009. Potassium diformate in the diet of reproducing sows: Effect on performance of sows and litters. Livestock Science 122: 241-247.

Palm M and Zacchi G, 2003. Extraction of hemicellulosic oligosaccharides from spruce using microwave oven or steam treatment. Biomacromolecules 4: 617-623.

Pan YC and Lee WC, 2005. Production of high-purity isomaltooligosaccharides syrup by the enzymatic conversion of transglucosidase and fermentation of yeast cells. Biotechnology and Bioengineering 89: 797-804.

Panesar PS et al., 2006. Microbial production, immobilization and applications of $\beta$-D-galactosidase. Journal of Chemical Technology and Biotechnology 81: 530-543.

Park HY et al., 2008. Galacto-oligosaccharide production by a thermostable $\beta$-galactosidase from Sulfolobus solfataricus. World Journal of Microbiology and Biotechnology 24: 1553-1558.

Partanen KH and Morz Z, 1999. Organic acids for performance enhancement in pig diets. Nutrition Research Review 12: 117-145.

Paul PS, 1990. Applications of nucleic acid probes in veterinary infectious diseases. Veterinary Microbiology 24: 409-417.

Pearlin BV et al., 2019. Role of acidifiers in livestock nutrition and health: A review. Journal of Animal Physiology and Animal Nutrition 104: 558-569.

Perry FG, 1995. Biotechnology in animal feeds and animal feeding: An overview. In: Wallace RJ and Chesson A (editors), Biotechnology in Animal Feeds and Animal Feeding, VCH, Weinheim, Germany; pp: 1-16.

Phillips I et al., 2004. Does the use of antibiotics in food animals pose a risk to human health? A critical review of published data. Journal of Antimicrobial Chemotherapy 53: 28-52.

Placier G et al., 2009. Evolved betagalactosidases from Geobacillus stearothermophilus with improved transgalactosylation yield for galacto-oligosaccharide production. Applied Environmental Microbiology 75: 6312-6321.

Prasad S and Roy I, 2018. Converting enzymes into tools of industrial importance. Recent Patents on Biotechnology 12: 33-56. 
Rajeev R et al., 2011. Molecular diagnosis of Haemorrhagic Septicaemia - A review. Veterinary World 4: 189-192.

Ramteke R et al., 2019. Antinutritional factors in feed and fodder used for livestock and poultry feeding. Acta Scientific Nutritional Health 3: 39-48.

Ravindran V et al., 1999. Influence of microbial phytase on apparent ileal amino acid digestibility of feedstuffs for broilers. Poultry Science 78: 677-706.

Ravindran V et al., 20oo. Response of broiler chickens to microbial phytase supplementation as influenced by dietary phutic acid and non-phytate phopophorus levels: II. Effects on apparent metabolisable energy, nutrient digestibility and nutrient retention. British Poultry Science 41: 193-200.

Refat B et al., 2018. Effect of fibrolytic enzymes on lactational performance, feeding behavior, and digestibility in high-producing dairy cows fed a barley silage-based diet. Journal of Dairy Science 101: 79717979 .

Rekha V et al., 2014. Loop mediated isothermal amplification (LAMP) test - A novel nucleic acid based assay for disease diagnosis. Advances in Animal and Veterinary Sciences 2: 344-350.

Rioux KP et al., 2005. The role of enteric microflora in inflammatory bowel disease: Human and animal studies with probiotics and prebiotics. Gastroenterology Clinics of North America 34: 465482.

Roberfroid M, 2007. Prebiotics: The concept revisited. Journal of Nutrition 137: 830S-837S.

Rodriguez J, 1997. Detection of animal pathogens by using the polymerase chain reaction (PCR). The Veterinary Journal 153: 287-305.

Rostami F et al., 2015. Effect of Scrophularia striata and Ferulago angulata, as alternatives to virginiamycin, on growth performance, intestinal microbial population, immune response, and blood constituents of broiler chickens. Poultry Science 94: 2202-2209.

Roth $\mathrm{N}$ et al., 2017. Effect of an organic acids based feed additive and enrofloxacin on the prevalence of antibiotic-resistant $E$. coli in cecum of broilers. Poultry Science 96: 4053-406o.

Rust SR et al., 20oo. Effects of Bovamine TM rumen culture on the performance and carcass characteristics of feedlot steers. Mich. Agric. Exp. Sta. Beef Cattle, Sheep and Forage Syst. Res. Dem. Rep. no. 569: 22-26.

Said S et al., 2005. Produksi anak sapi potong dan sapi perah berjenis kelamin sesuai harapan. Prosiding Seminar Nasional Industri Peternakan Modern II. (Mataram Juli 19-20) pp: 209-216.

Said S et al., 2020. The role of biotechnology in animal production. The $2^{\text {nd }}$ International Conference of Animal Science and Technology. IOP Conf. Series: Earth and Environmental Sciences 492: Article \# 012035 .

Salem AZM et al., 2011. Effects of exogenous enzymes on nutrients digestibility and growth performance in sheep and goats. Tropical and Subtropical Agrosystems 14: 867-874.

Salim HM et al., 2013. Supplementation of direct-fed microbials as an alternative to antibiotic on growth performance, immune response, cecal microbial population, and ileal morphology of broiler chickens. Poultry Science 92: 2084-2090.

Saminathan $\mathrm{M}$ et al., 2016. Prevalence, diagnosis, management and control of important diseases of ruminants with special reference to Indian scenario. Journal of Experimental Biology and Agricultural Sciences $4: 338-367$.

Sander V et al., 2020. Use of veterinary vaccines for livestock as a strategy to control foodborne parasitic diseases. Frontiers in Cellular and Infection Microbiology 10: Article \# 288.

Santos AMP and Maugeri F, 2007. Synthesis of fructooligosaccharides from sucrose using inulinase from Kluyveromyces marxianus. Food Technology and Biotechnology 45: 181-186.

Sato $\mathrm{N}$ et al., 2010. Improvement in the productivity of xylooligosaccharides from waste medium after mushroom cultivation by hydrothermal treatment with suitable pretreatment. Bioresource Technology 101: 6006-6011.

Scavuzzi BM et al., 2014. Impact of prebiotics, probiotics and synbiotics on components of the metabolic syndrome. Annals of Nutritional Disorders and Therapy 1: 1009 .

Scott N, 2007. Nanoscience in veterinary medicine. Veterinary research communications 3: 139-144.

Shakweer W, 2008. Use of recombinant bovine somatotropin (rbst) to enhance productive and reproductive performance of sheep under different dietary energy levels. Research Gate. Thesis/desertation, National Research Centre, Egypt.

Sharma GK et al., 2015. Diagnostic assays developed for the control of foot-and-mouth disease in India. World Journal of Virology 4: 295-302.

Singhania RR et al., 2010. The industrial production of Enzymes. In: Soetart W and Vandamme EJ (editors.), Industrial Biotechnology. VCH, Weinheim, Germany; pp: 207-222.

Sinigaglia C et al., 2018. A safer, urea-based in situ hybridization method improves detection of gene expression in diverse animal species. Developmental Biology 434: 15-23.

Śliżewska K et al., 2013. Prebiotyki - definicja, właściwości i zastosowanie w przemyśle. ŻYWNOŚĆ Nauka Technolog Jakość 1: 5-20.

Sorndech W et al., 2018. Isomalto-oligosaccharides: Recent insights in production technology and their use for food and medical applications. LWT Food Science and Technology 95: 135-142.

Splechtna B et al., 2006. Production of prebiotic galactooligosaccharides from lactose using betagalactosidases from Lactobacillus reuteri. Journal of Agriculture and Food Chemistry 54: 4999-50o6.

Spratt CD, 1985. Effect of mould inhibitor treated high moisture corn on performance of poultry. M.Sc. Thesis, University of Guelph, Canada.

Steiner T, 2009. Probiotics in Poultry and Pig Nutrition: Basics and Benefits. The Poultry site. 
Stephany RW, 2009. Hormonal Growth Promoting Agents in Food Producing Animals. Handbook of Experimental Pharmacology 2010: 355-367.

Sujani S and Seresinhe RT, 2015. Exogenous enzymes in ruminant nutrition: A review. Asian Journal of Animal Sciences 9: 85-99.

Swinney-Floyd D et al., 1999. Effect of inoculation with either strain P-63 alone or in combination with Lactobacillus acidophilus LA53545 on performance of feedlot cattle. Journal of Animal Science 77.

Tang $\mathrm{X}$ et al., 2012. Dietary supplementation with recombinant lactoferrampin-lactoferricin improves growth performance and affects serum parameters in piglets. Journal of Animal and Veterinary Advances 11: 2548-2555.

Tang $\mathrm{Z}$ et al., 20o8. Effects of dietary supplementation with an expressed fusion peptide bovine lactoferricin actoferrampin on performance, immune function and intestinal mucosal morphology in piglets weaned at age $21 \mathrm{~d}$. British Journal of Nutrition 101: 998-1005.

Tappa B et al., 1994. Response of dairy cows treated and repeated superovulation and embryo recovery. Proceedings of the 7 th AAAP Animal Science Congress July 11-16, Bali, Indonesia; pp: 19-20.

Teng $C$ et al., 2010. Production of xylooligosaccharides from the steam explosion liquor of corncobs coupled with enzymatic hydrolysis using a thermostable xylanase. Bioresource Technology 101: 7679-7682.

Thibier M, 2005. Significant increases in transfers of both in vivo derived and in vitro produced embryos in cattle and contrasted trends in other species. In IETS Newsletter 23: 11-17.

Thornton PK, 2010. Livestock production: Recent trends, future prospects. Philosophical Transactions of the Royal Society of London Series B Biological Sciences 365: 2853-2867.

Tilman D et al., 2011. Global food demand and the sustainable intensification of agriculture. Proceedings of the National Academy of Sciences of the United States of America 108: 20260-20264.

Tirado-Gonzalez DN et al., 2018. Meta-analysis: Effects of exogenous fibrolytic enzymes in ruminant diets. Journal of Applied Animal Research 46: 771-783.

Tizard I, 2020. Types of vaccines for animals. Accessible at:

https://www.msdvetmanual.com/pharmacology/vacci nes-and-immunotherapy/types-of-vaccines-for-

animals. Last modified: July 2020. Accessed on: June $1^{\text {st }}, 2021$.

Transparency MR, 2019. Animal feed probiotics market Global industrial analysis, size, share, growth, trends, and forecast 2019-2027. Available at: https://www.transparencymarketresearch.com/anima l-feed-probiotics-market.html

Umesaki Y et al., 1997. Interactions between epithelial cells and bacteria, normal and pathogenic. Science Magazine pp. 9.

Vazquez MJ et al., 2005. Refining of autohydrolysis liquors for manufacturing xylo-oligosaccharides: Evaluation of operational strategies. Bioresource Technology 96:
$889-896$.

Vom Steeg LG and Klein SL, 2017. Sex steroids mediate bidirectional interactions between hosts and microbes. Hormones and Behavior 88: 45-51.

Waghu FH et al., 2014. Camp: Collection of sequences and structures of antimicrobial peptides. Nucleic Acids Research 42: D1154-D1158.

Wang Y, 2009. Prebiotics: Present and future in food science and technology. Food Research International 42: 8-12.

WHO. Environmental health criteria, No.136. Environmental aspects, Geneva, 1994.

WHO, 2003. Joint FAO/OIE/WHO Expert Workshop on non-human antimicrobial usage and antimicrobial resistance: scientific assessment, Geneva, December 15, 2003. Geneva, Switzerland.

WHO, 2004. Second Joint FAO/OIE/WHO Expert Workshop on non-human antimicrobial usage and antimicrobial resistance: Management options. Geneva, Switzerland.

WHO, 2015. WHO estimates of the global burden of foodborne diseases. Geneva, Switzerland.

Wilmut I et al., 1997. Viable offspring derived from fetal and adult mammalian cells. Nature 385: 810-813.

Womack JE, 2005. Advances in livestock genomics: Opening the barn door. Genome Research 15: 16991705 .

$\mathrm{Wu} \mathrm{S}$ et al., 2012. Effects of the antimicrobial peptide cecropin $\mathrm{AD}$ on performance and intestinal health in weaned piglets challenged with Escherichia coli. Peptides 35: 225-230.

Xiao $\mathrm{H}$ et al., 2013a. Effects of composite antimicrobial peptides in weanling piglets challenged with deoxynivalenol: I. Growth performance, immune function, and antioxidation capacity. Journal of Animal Science 91: 4772-4780.

Xiao $\mathrm{H}$ et al., 2013b. Effects of composite antimicrobial peptides in weanling piglets challenged with deoxynivalenol: II. Intestinal morphology and function. Journal of Animal Science 91: 4750-4756.

Xiao $\mathrm{H}$ et al., 2015. Metabolic profiles in the response to supplementation with composite antimicrobial peptides in piglets challenged with deoxynivalenol. Journal of Animal Science 93: 1114-1123.

Xiong X et al., 2014. Effects of antimicrobial peptides in nursery diets on growth performance of pigs reared on five different farms. Livestock Science 167: 206-210.

Yanchinski S, 1983. Slow progress seen for biotechnology in animal health. Nature Biotechnology 1: 831-833.

Yang $\mathrm{H}$ et al., 2011. Production of xylo-oligosaccharides by xylanase from Pichia stipitis based on xylan preparation from triploid Populas tomentosa. Bioresource Technology 102: 7171-7176.

Yirga H, 2015. The use of probiotics in animal nutrition. Journal of Probiotics and Health 3: Article \# 1000132.

Yoon JH et al., 2012. Effects of dietary supplementation of antimicrobial peptide-A3 on growth performance, nutrient digestibility, intestinal and fecal microflora and intestinal morphology in weanling pigs. Animal Feed Science and Technology 177: 98-107. 
Yoon JH et al., 2013. Effects of dietary supplementation with antimicrobial peptide- $\mathrm{P}_{5}$ on growth performance apparent total tract digestibility, faecal and intestinal microflora and intestinal morphology of weanling pigs. Journal of Science of Food Agriculture 93: 587-592.

Yoshikawa J et al., 2007. Purification and some properties of beta-fructofuranosidase I formed by Aureobasidium pullulans DSM 2404. Journal of Bioscience and Bioengineering 103: 491-493.

Zarlenga DS and Higgins J, 2001. PCR as a diagnostic and quantitative technique in veterinary parasitology. Veterinary Parasitology 101: 215-230.
Zhang Z and Kornegay ET, 1999. Phytase effects on ileal amino acid digestibility and nitrogen balance in finishing pigs fed a low-protein plant-based diet. Journal of Animal Science 77: Article \# 1.

Zhang $L$ et al., 2010. Sandwich-structured enzyme membrane reactor for efficient conversion of maltose into isomalto-oligosaccharides. Bioresource Technology 101: 9144-9149.

Zuccato E et al., 2010. Source, occurrence and fate of antibiotics in the Italian aquatic environment. Journal of Hazardous Materials 179: 1042-1048. 